Chemical Engineering

Division

Chemical Engineering

Division

Chemical Engineering

Division

Chemical Engineering

Division

Chemical Engineering

Division

Chemical Engineering

Division

Chemical Engineering

Division

Chemical Engineering

Division

\title{
Review of Arsenic Removal Technologies for Contaminated Groundwaters
}

\author{
by K. B. Vu, M. D. Kaminski
} and L. Nuñez

Chemical Engineering

Division

Chemical Engineering

Division

Chemical Engineering

Division

Chemical Engineering

Division

Chemical Engineering

Division

Chemical Engineering

Division

Chemical Engineering

Division

Chemical Engineering

Division

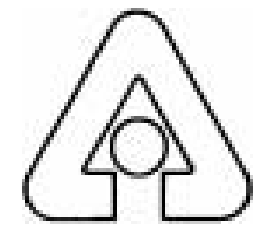

Argonne National Laboratory, Argonne, Illinois 60439

operated by The University of Chicago

for the United States Department of Energy under Contract W-31-109-Eng-38

Chemical Engineering

Division

Chemical Engineering

Division

Chemical Engineering

Division

Chemical Engineering

Division 
Argonne National Laboratory, with facilities in the states of Illinois and Idaho, is owned by the United States Government and operated by The University of Chicago under the provisions of a contract with the Department of Energy.

\section{DISCLAIMER}

This report was prepared as an account of work sponsored by an agency of the United States Government. Neither the United States Government nor any agency thereof, nor The University of Chicago, nor any of their employees or officers, makes any warranty, express or implied, or assumes any legal liability or responsibility for the accuracy, completeness, or usefulness of any information, apparatus, product, or process disclosed, or represents that its use would not infringe privately owned rights. Reference herein to any specific commercial product, process, or service by trade name, trademark, manufacturer, or otherwise, does not necessarily constitute or imply its endorsement, recommendation, or favoring by the United States Government or any agency thereof. The views and opinions of document authors expressed herein do not necessarily state or reflect those of the United States Government or any agency thereof, Argonne National Laboratory, or The University of Chicago.

Available electronically at http://www.doe.gov/bridge

Available for a processing fee to U.S. Department of Energy and its contractors, in paper, from:

\section{U.S. Department of Energy}

Office of Scientific and Technical Information

P.O. Box 62

Oak Ridge, TN 37831-0062

phone: (865) 576-8401

fax: (865) 576-5728

email: reports@adonis.osti.gov 


\title{
ANL-CMT-03/2 \\ Argonne National Laboratory \\ 9700 South Cass Avenue \\ Argonne, IL 60439 \\ REVIEW OF ARSENIC REMOVAL TECHNOLOGIES FOR CONTAMINATED GROUNDWATERS
}

\author{
Kiem B. Vu, Michael D. Kaminski, and Luis Nuñez
}

Chemical Engineering Division

April 2003 


\section{CONTENTS}

Page

ABSTRACT.

1. INTRODUCTION ................................................................................ 2

2. ARSENIC CHEMISTRY ............................................................................. 3

2.1 ARSENIC FORMS AND MOBILITY ........................................................ 3

2.2 EFFECTS OF pH AND REDOX POTENTIAL ........................................ 3

3. GROUNDWATER ENVIRONMENTS ............................................................. 5

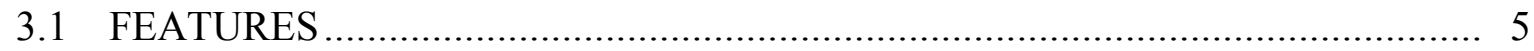

3.2 TRIGGERS FOR DISSOLUTION OF ARSENIC FROM MINERALS ............... 5

4. DISTRIBUTION OF ARSENIC IN GROUNDWATERS WORLDWIDE ................... 6

4.1 REDUCING ENVIRONMENT: BANGLADESH, WEST BENGAL, VIETNAM, CHINA AND TAIWAN ........................................................ 6

4.2 ARID OXIDIZING ENVIRONMENT: ARGENTINA, MEXICO

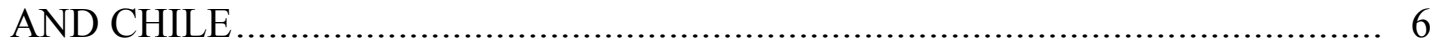

4.3 AREAS AFFECTED BY MINING ......................................................... 7

4.4 SUMMARY …................................................................................. 7

5. OVERVIEW OF ARSENIC TREATMENTS .................................................. 9

5.1 ADSORPTION AND CHEMICAL PRECIPITATION TREATMENTS.............. 9

5.1.1 Ferric Salts and Aluminum Alum ..................................................... 9

5.1.2 Iron Filings................................................................................ 10

5.1.3 Gravel Bed Containing Iron-Coated Sand ............................................ 12

5.1.4 Gravel Bed Containing Iron Sludge ........................................................ 12

5.1.5 Lanthanum Compounds...................................................................... 13

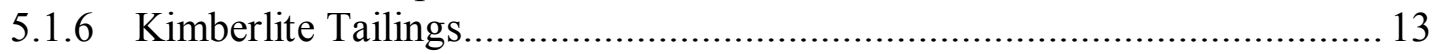

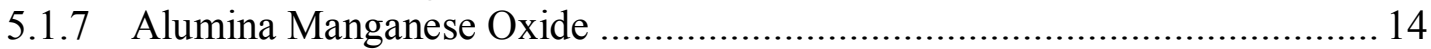

5.1.8 Activated Alumina .......................................................................... 14

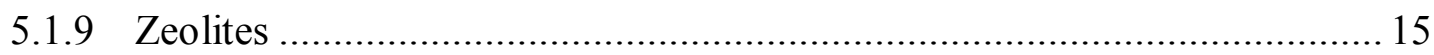

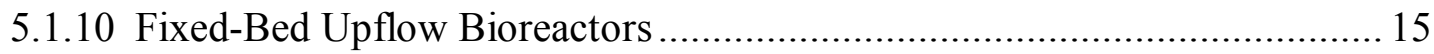

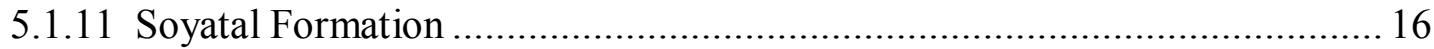

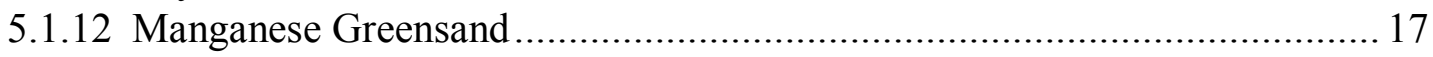

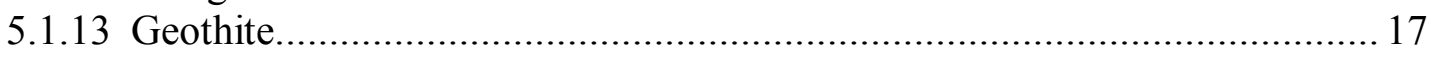

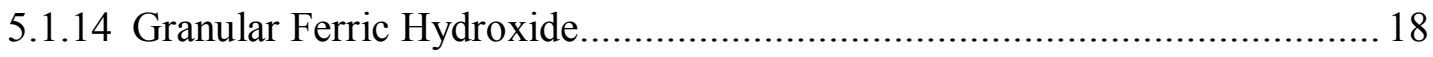

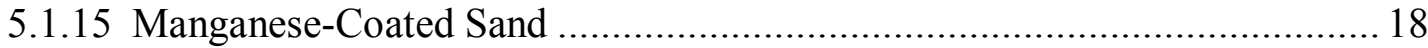

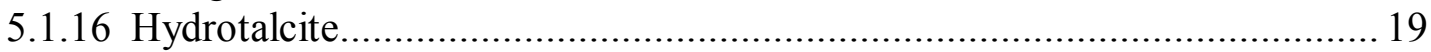

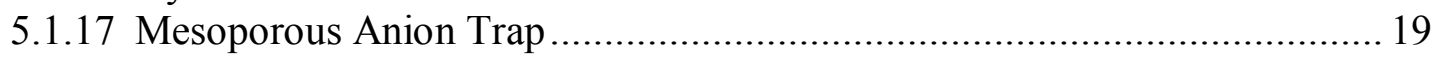

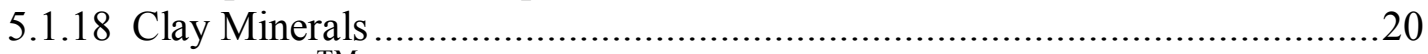

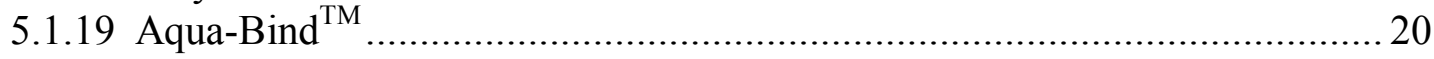

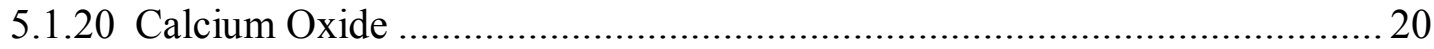

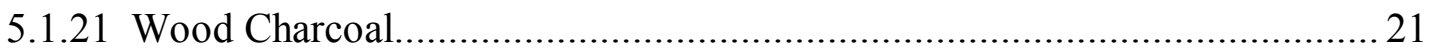




\section{CONTENTS}

(Continued)

Page

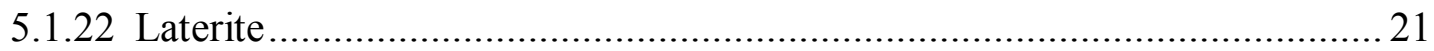

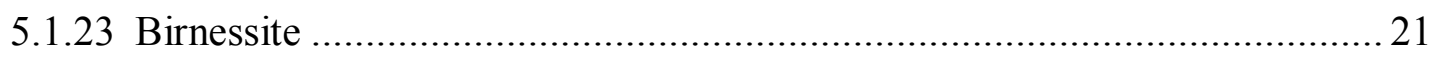

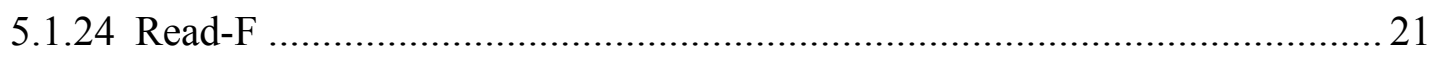

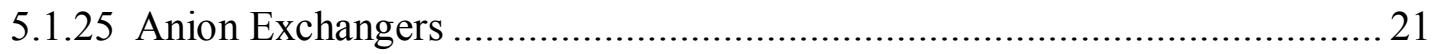

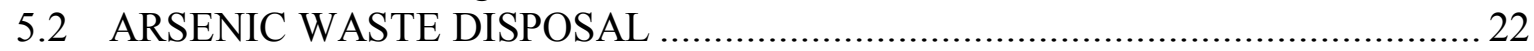

6. CHEMISTRY AND MECHANISMS OF SOME MAJOR SORBENTS ...........................2 26

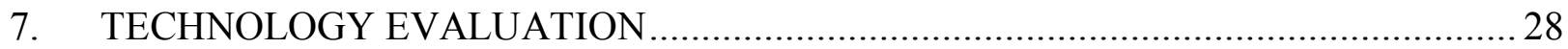

8. FUTURE OPPORTUNITY: REMOVAL OF ARSENIC USING MAGNETIC

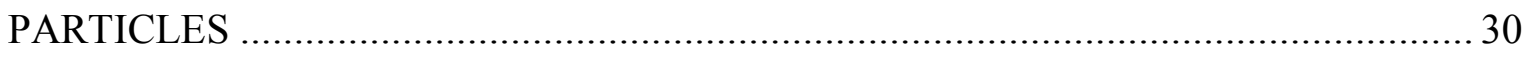

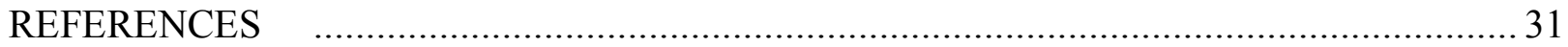




\section{TABLES}

Page

1. Stability of Arsenic Species ……....................................................................... 3

2. Major Countries Facing Serious Arsenic Contamination in Drinking Water................... 8

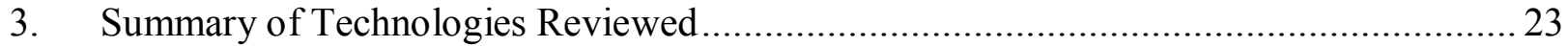

\section{FIGURES}

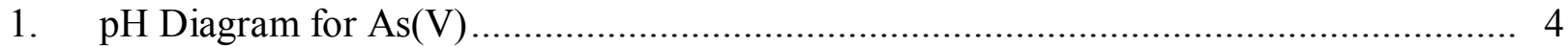




\begin{abstract}
This review was compiled to summarize the technologies currently being investigated to remove arsenic from drinking waters, with a special focus on developing and third-world countries where the problem is exacerbated by flooding and depressed economic conditions. The reason for compiling this report is to provide background material and a description of competing technologies currently described in the literature for arsenic removal. Based on the sophistication and applicability of current technologies, Argonne National Laboratory may develop an improved method based on magnetic particle technology. Magnetic particle sorbents may afford improved reaction rates, facilitate particle-water separation, and offer reusability.

Developing countries like Vietnam and Bangladesh cannot afford expensive, large-scale treatments to remove arsenic from drinking waters to acceptable limits (from $50 \mathrm{ppb}$ to $10 \mathrm{ppb}$, depending on the country). Low-cost, effective technologies that can be readily available at the household or community level are needed to solve the present crisis. Appropriate technologies should meet certain criteria, including the following:

- The treatment must be applicable over a wide range of arsenic concentrations.

- It should be easy to use without running water or electricity.

- The materials for the treatment should be cheap and readily available, and/or suitable for reuse.

Our review of arsenic removal technologies and procedures indicates that iron filings, ferric salts, granular ferric hydroxide, alumina manganese oxide, Aqua-bind ${ }^{\mathrm{TM}}$, and Kimberlite tailings are potentially low-cost sorbents that can remove arsenic after simple mixing in a relatively short time. However, all these technologies suffer from significant shortcomings. Ferric salts are cheap and very effective at removing arsenic but the reaction rates are slow. Fixed-bed columns make use of activated alumina and iron-coated sands but do not work well with groundwater having high concentrations of iron because iron precipitates in the presence of air, which could clog and foul the column. Synthetic sorbents are highly selective and effective and do not pose a significant waste disposal concern because they are generally non-hazardous. Aqua-bind $^{\mathrm{TM}}$ is perhaps the most effective synthetic sorbent available for removing arsenic, but it must be mass-produced to realize low cost. Naturally occurring solids are cheap and remove arsenic well; however, the removal rate is often very slow and the solids can harbor bacteria. This report reviews competing technologies for removal of water-borne arsenic to establish a baseline for technology improvements. Specifically, the information in this report will serve as a basis for developing a low-cost separation technology using functionalized magnetic particles to adsorb arsenic and permanent magnets to separate the arsenic-loaded magnetic particles from the cleaned water.
\end{abstract}




\section{INTRODUCTION}

Arsenic is a well-known toxic metal and is present mainly as oxyanion compounds in groundwater (1). The World Health Organization's (WHO's) current provisional guideline for arsenic in drinking water is $10 \mu \mathrm{g} / \mathrm{L}$, but all developing countries affected with contaminated groundwater are still struggling to keep up with the previous WHO guideline value of $50 \mu \mathrm{g} / \mathrm{L}$ (2). Chronic exposure to arsenic $>50 \mu \mathrm{g} / \mathrm{L}$ in drinking water can result in serious health problems. Symptoms of chronic exposure to groundwater contaminated with arsenic at concentrations significantly $>50 \mu \mathrm{g} / \mathrm{L}$ include skin, cardiovascular, renal, hematological and respiratory disorders (1). An estimated 300,000 people in West Bengal alone suffer from arsenic-induced skin lesions. Serious illnesses related to arsenic such as melanosis, keratosis, cancer, and gangrene have been reported in West Bengal and Bangladesh (3).

Arsenic contamination of drinking water is presently a worldwide epidemic. Contaminated drinking water has been found in Argentina, Chile, Mexico, China, Hungary, West Bengal, Bangladesh and Vietnam. Of these regions, West Bengal and Bangladesh are most seriously affected in terms of the size of the population at risk and the magnitude of the health problems. A recent survey of shallow groundwater aquifers in Bangladesh showed that $27 \%$ of the aquifers have arsenic concentrations $>50 \mu \mathrm{g} / \mathrm{L}$ (2). Although the percentage does not seem remarkably high, it is alarming considering that more than $90 \%$ of the rural population in Bangladesh gets drinking from 4-5 million tubewells (4).

Most of arsenic problems in third-world countries today are caused by natural erosion. One important mechanism through which the groundwater is polluted with arsenic is the reduction of iron oxyhydroxide $(\mathrm{FeOOH})$ by bacteria and subsequent desorption of arsenic from the iron surfaces. In the Bengal Basin (part of Bangladesh and West Bengal), it is the main mechanism by which groundwaters become contaminated with arsenic (5). That does not mean humans are exempted from blame for the present arsenic crisis; significant arsenic pollution has occurred through the use of pesticides, herbicides, crop desiccants and additives to animal feed (6). The impact of producing arsenic-containing chemicals on the environment was felt by Calcutta, India, where more than 7,000 people consumed arsenic-contaminated water caused by the release of arsenic through the manufacturing of insecticides by a chemical factory in the region (7).

The focus of this report is on current technologies for arsenic removal through adsorption, precipitation, and coprecipitation processes. These processes make use of inorganic sorbents and adsorption medias, such as ferric chloride and iron-oxide-coated sand. Precipitation involves the formation of insoluble compounds, adsorption involves the electrostatic binding of arsenic to metal hydroxide surfaces, and coprecipitation involves the incorporation of soluble arsenic species into a growing metal hydroxide phase (8). Most technologies utilizing those processes require an oxidation pretreatment to convert $\mathrm{As}(\mathrm{III})$ to $\mathrm{As}(\mathrm{V})$ because $\mathrm{As}(\mathrm{V})$ adsorbs and reacts more strongly onto the solid phase than does As(III). 


\section{ARSENIC CHEMISTRY}

\subsection{ARSENIC FORMS AND MOBILITY}

Arsenic rarely occurs in a free state and is found largely in combination with sulfur, oxygen, and iron. In groundwater, arsenic combines with oxygen to form inorganic pentavalent arsenate and trivalent arsenite. Unlike other heavy metalloids and oxyanion-forming elements, arsenic can be mobilized under a wide range of oxidizing and reducing conditions at the $\mathrm{pH}$ values typically found in groundwaters $(\mathrm{pH}$ 6.5-8.5). Whereas all other oxyanion-forming elements are found within the $\mu \mathrm{g} / \mathrm{L}$ range, arsenic can be found within the $\mathrm{mg} / \mathrm{L}$ range (9).

Arsenic has four main chemical forms having oxidation states, $-3,0,+3$, and +5 , but in natural water its predominant forms are inorganic oxyanions of trivalent arsenite $\left(\mathrm{As}^{3+}\right)$ or pentavalent arsenate $\left(\mathrm{As}^{5+}\right)$ (9). The toxicity of different arsenic species varies in the order arsenite $>$ arsenate $>$ monomethylarsonate $>$ dimethylarsinate. Trivalent arsenic is about 60 times more toxic than arsenic in the oxidized pentavalent state, and inorganic arsenic compounds are about 100 times more toxic than organic arsenic compounds (10). The organic forms of arsenic are quantitatively insignificant and are found mostly in surface waters or in areas severely affected by industrial pollution (9). The relative concentrations of As(III) to As(V) vary widely, depending on the redox conditions in the geological environment (10).

\subsection{EFFECTS OF $\mathrm{pH}$ AND REDOX POTENTIAL}

The two most important factors controlling the speciation of arsenic (and, to some extent, solubility) are $\mathrm{pH}$ and redox potential. Under oxidizing conditions at $\mathrm{pH}$ less than $6.9, \mathrm{H}_{2} \mathrm{AsO}_{4}{ }^{-}$ is the dominant species, whereas $\mathrm{HAsO}_{4}{ }^{-2}$ predominates at higher $\mathrm{pH}$. Under reducing conditions at a $\mathrm{pH}$ value less than 9.2, the uncharged arsenite species $\mathrm{H}_{3} \mathrm{AsO}_{3}$ is dominant. In contrast to the $\mathrm{pH}$ dependency of $\mathrm{As}(\mathrm{V}), \mathrm{As}(\mathrm{III})$ was found virtually independent of $\mathrm{pH}$ in the absence of other specifically adsorbed anions (9). Most often, more trivalent arsenic than pentavalent arsenic is found in reducing groundwater conditions, whereas the converse is true in oxidizing groundwater conditions. The stabilities of arsenic species under different $\mathrm{pH}$ and redox conditions are shown in Table 1 (11).

Table 1. Stability of Arsenic Species

\begin{tabular}{|c|c|c|c|}
\hline \multicolumn{2}{|c|}{ Reducing Conditions } & \multicolumn{2}{c|}{ Oxidizing Conditions } \\
\hline $\mathbf{p H}$ & $\mathbf{A s}(\mathbf{I I I})$ & $\mathbf{p H}$ & $\mathbf{A s}(\mathbf{V})$ \\
\hline $0-9$ & $\mathrm{H}_{3} \mathrm{AsO}_{3}$ & $0-2$ & $\mathrm{H}_{3} \mathrm{AsO}_{4}$ \\
\hline $10-12$ & $\mathrm{H}_{2} \mathrm{AsO}_{3}{ }^{-}$ & $3-6$ & $\mathrm{H}_{2} \mathrm{AsO}_{4}{ }^{-}$ \\
\hline 13 & $\mathrm{HAsO}_{3}{ }^{2-}$ & $7-11$ & $\mathrm{HAsO}_{4}{ }^{2-}$ \\
\hline 14 & $\mathrm{AsO}_{3}{ }^{3-}$ & $12-14$ & $\mathrm{AsO}_{4}{ }^{3-}$ \\
\hline
\end{tabular}




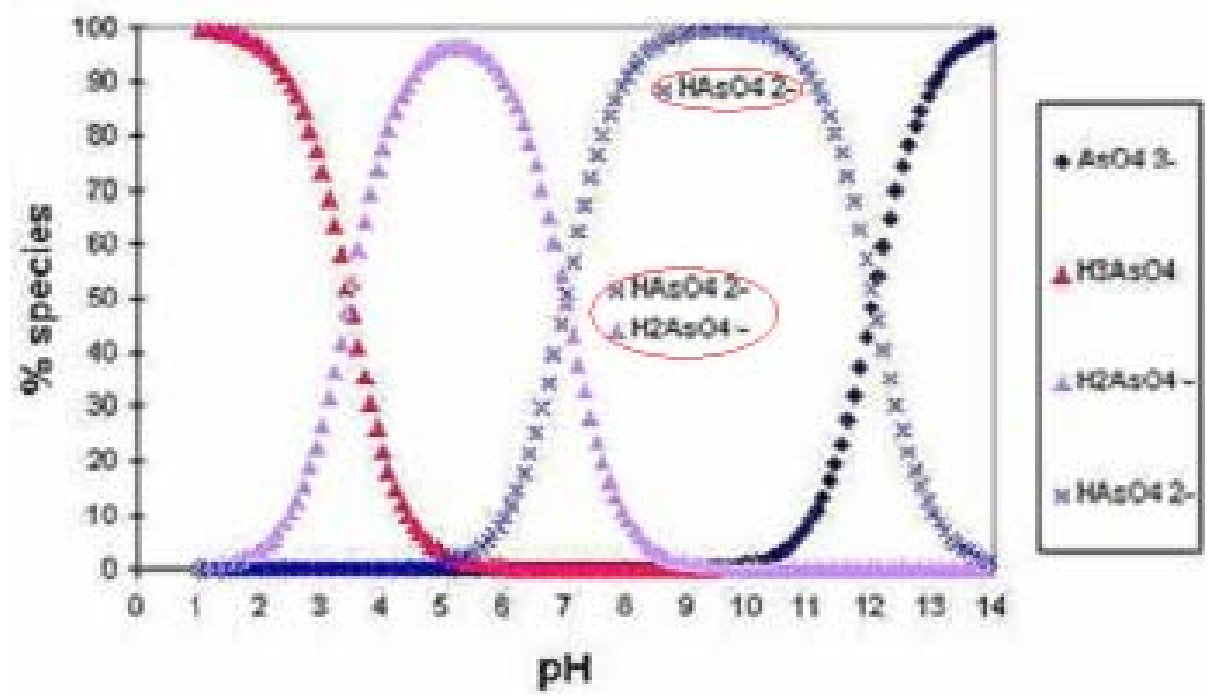

Fig. 1. $\mathrm{pH}$ diagram for $\mathrm{As}(\mathrm{V})$

Unlike other toxic trace metals whose solubilities tend to decrease as $\mathrm{pH}$ increases, most oxyanions, including arsenate $\left(\mathrm{As}^{5+}\right)$, tend to become more soluble as $\mathrm{pH}$ increases (Fig. 1). When most other metals become insoluble within the neutral $\mathrm{pH}$ range, arsenic is soluble at even near-neutral $\mathrm{pH}$ in relatively high concentrations. That is why groundwaters are easily contaminated with arsenic and other oxyanions (9). 


\section{GROUNDWATER ENVIRONMENTS}

\section{$3.1 \quad$ FEATURES}

High-arsenic groundwaters are usually present in two types of environment: inland or closed basins in arid or semi-arid areas (an oxidizing environment) and in strongly reducing aquifers. Both environments contain young sediments where water flow is slow enough to allow arsenic to accumulate. As(III) is usually the predominant species under reducing conditions, whereas $\operatorname{As}(\mathrm{V})$ usually predominates under oxidizing conditions. The extent of arsenic presence in groundwater is very small compared with the levels in associated minerals, particularly Fe oxides. In the presence of metal oxides, most arsenic becomes immobilized either through compound formation or adsorption. Desorption of arsenic from the minerals could pose serious problems because only a small percentage of As is needed to dissolve or desorb and render groundwaters unsafe for consumption (9).

\subsection{TRIGGERS FOR DISSOLUTION OF ARSENIC FROM MINERALS}

There are two main triggers that lead to the release of arsenic from its solid-iron oxide phase (9). The first is a $\mathrm{pH}$ change under oxidizing conditions, and the second is the development of strongly reducing conditions at near-neutral $\mathrm{pH}$. Under oxidizing conditions at $\mathrm{pH}<8.5$, most As adsorbs strongly to metal oxides as $\mathrm{As}(\mathrm{V})$. At $\mathrm{pH}>8.5$, As(V) desorbs from the oxide surfaces, raising the total concentration of arsenic in groundwater. Some factors that may be responsible for the increase in $\mathrm{pH}$ in oxidizing environments are the effect of other anions, especially phosphate; the uptake of protons in solution due to weathering and ionexchange reactions; and the effect of evaporation in arid and semi-arid regions. The most common factor that is responsible for creating reducing condition at near-neutral $\mathrm{pH}$ is the rapid accumulation of young sediments. Arsenic release under reducing conditions has many possible causes, such as dissolution of arsenic-containing minerals (9). 


\title{
4. DISTRIBUTION OF ARSENIC IN GROUNDWATERS WORLDWIDE
}

\author{
4.1 REDUCING ENVIRONMENT: BANGLADESH, WEST BENGAL, VIETNAM, \\ CHINA, AND TAIWAN
}

Approximately 30-35 million people in Bangladesh and 7 million people in West Bengal are exposed to elevated levels of arsenic in drinking water. Arsenic concentrations were found from $>0.5 \mu \mathrm{g} / \mathrm{L}$ to $3200 \mu \mathrm{g} / \mathrm{L}$, with As(III) present as the dominant species. The relative ratio of dissolved $\mathrm{As}(\mathrm{III})$ to $\mathrm{As}(\mathrm{V})$ is often greater than 1 because $\mathrm{As}(\mathrm{III})$ is more mobile under reducing conditions. The groundwaters in these regions usually have high iron content, as well. High concentrations of arsenic are more often found in shallow wells (100-150 m deep). About 27\% of shallow wells less than $150 \mathrm{~m}$ deep have arsenic concentrations $>50 \mu \mathrm{g} / \mathrm{L}$, whereas wells greater than 150-200 m deep usually have arsenic concentration $<5 \mu \mathrm{g} / \mathrm{L}(9)$.

The Bengal Delta and North Vietnam have similar reducing geological features, with relatively young alluvial sediments and anoxic groundwaters (12). Many Vietnamese depend on aquifers of the large deltas of the Mekong and Red Rivers for drinking water. More than 10 million people are exposed to harmful arsenic concentrations from drinking well water (9). The groundwaters usually have high concentrations of $\mathrm{Fe}, \mathrm{Mn}$, and $\mathrm{NH}_{4}$. Shallow tube wells in Hanoi have been found to have significant concentrations of As, ranging from 1 to $3050 \mu \mathrm{g} / \mathrm{L}$ (mean $=159$ ). Investigations of tube wells indicated that arsenic concentrations in $48 \%$ of them were $>50 \mu \mathrm{g} / \mathrm{L}(20 \%$ were $>150 \mu \mathrm{g} / \mathrm{L})$. In highly affected areas, the groundwaters had an average arsenic concentration of $430 \mu \mathrm{g} / \mathrm{L}$ (12). Arsenic contamination in Vietnam was not well understood until recently, and the work is ongoing to better understand the problem (9).

China faces similar contamination, with more than 5 million people exposed to arsenic from drinking contaminated groundwater. Inner Mongolia and the Xinjiang and Shanxi Provinces in Northern China were found to have high arsenic concentrations in groundwater. Concentrations of arsenic ranged from 40 to $750 \mu \mathrm{g} / \mathrm{L}$ in deep artesian groundwater from Dzungaria Basin on the north side of the Tianshan Mountains. High arsenic concentrations were found less frequently in non-artesian groundwater, however. In Inner Mongolia, aquifers were found to have arsenic concentrations $>50 \mu \mathrm{g} / \mathrm{L}$, with As(III) present as the dominant species (60$90 \%$ of the total). (9)

\subsection{ARID OXIDIZING ENVIRONMENT: ARGENTINA, MEXICO, AND CHILE}

Oxidizing groundwater environments favor mobilization of $\mathrm{As}(\mathrm{V})$ at above-neutral $\mathrm{pH}$. Below $\mathrm{pH} 8.5$, arsenate strongly adsorbs to the mineral oxides or becomes part of the mineral structure. Some large areas in Argentina, Mexico, and Chile were found to have arseniccontaminated groundwater under oxidizing conditions (9). Of those regions, groundwaters from the Chaco-Pampean Plain of central Argentina were most seriously affected. The groundwaters there also had low dissolved $\mathrm{Fe}$ and $\mathrm{Mn}$ concentrations (in contrast to high $\mathrm{Fe}$ and $\mathrm{Mn}$ oxides under reducing conditions) and typically had high salinity and neutral-to-high $\mathrm{pH}$. Several studies were carried out to determine the severity of the problem in some provinces of the Chaco-Pampean Plain. Arsenic concentrations ranged from $<10$ to $720 \mu \mathrm{g} / \mathrm{L}$ (mean $201 \mu \mathrm{g} / \mathrm{L}$ ) in Cordoba and Santa Fe, $<4$ to $5280 \mu \mathrm{g} / \mathrm{L}$ (median $145 \mu \mathrm{g} / \mathrm{L}$ ) in La Pampa, and 12 to $1660 \mu \mathrm{g} / \mathrm{L}$ 
(median $46 \mu \mathrm{g} / \mathrm{L}$ ) in Tucuman (9). The primary factor in their mobilization was believed to be arsenic-bound metal oxides, especially $\mathrm{Fe}$ and $\mathrm{Mn}$ oxides under high $\mathrm{pH}$ conditions. In La Pampa province, $\mathrm{As}(\mathrm{III}) / \mathrm{As}(\mathrm{V})$ ratios typically were low at about 0.017 , mostly as $\mathrm{As}(\mathrm{V})(1)$.

Problems due to arsenic contamination have also affected Central America. Significant chronic arsenic-related health problems have arisen in the Lagunera Region in Northern Mexico. Groundwater is an important source of drinking water there because the region is arid. The groundwater environment is predominantly oxidizing, with neutral-to-high $\mathrm{pH}$ (6.3-8.9). The main form of arsenic present in the region is $\mathrm{As}(\mathrm{V})$, and total arsenic concentrations are 8 to $624 \mu \mathrm{g} / \mathrm{L}($ mean $=100 \mu \mathrm{g} / \mathrm{L})$ with $50 \%$ of the groundwater samples investigated having arsenic concentrations $>50 \mu \mathrm{g} / \mathrm{L}$. The exposed population was estimated at more than 400,000 in the Lagunera Region (9).

In South American, Chile's Administrative Region II was seriously affected by high concentrations of arsenic in both surface and groundwaters. Water resources in the region are limited because of arid conditions. Arsenic concentrations in both surface and groundwaters are usually $>100 \mu \mathrm{g} / \mathrm{L}$, with arsenate anion present as the main species. Although arsenic treatment plants were installed in the towns several decades ago, rural populations still rely largely on groundwater for drinking (9).

\subsection{AREAS AFFECTED BY MINING}

Mining activities can also cause release of arsenic into groundwater. About 1,000 people were diagnosed with arsenic-related skin disorders in the Ron Phibun District in Nakhon Si Thammarat Province of southern Thailand in the late 1990s. Arsenic concentrations up to $5000 \mu \mathrm{g} / \mathrm{L}$ were found in shallow groundwater, induced or exacerbated by mine workings. Another important mining area is the Ashanti Region of central Ghana, but arsenic was found at surprisingly low concentrations in the region. Some mining areas in the USA also are seriously contaminated by arsenic, such as the Fairbanks, Alaska, gold-mining district, the Leviathan Mine in California, and Kelly Creek Valley, Nevada. (9).

\subsection{SUMMARY}

Table 2 summarizes the contamination problems in the countries discussed in the preceding sections of this report. 
Table 2. Major Countries Facing Serious Arsenic Contamination in Drinking Water ${ }^{\mathrm{a}}$

\begin{tabular}{|c|c|c|c|c|}
\hline Country/Region & $\begin{array}{l}\text { Population } \\
\text { Exposed }\end{array}$ & $\begin{array}{c}\text { Concentration } \\
\text { Range, } \mu \mathrm{g} / \mathrm{L}\end{array}$ & $\begin{array}{c}\text { Groundwater } \\
\text { Properties }\end{array}$ & $\begin{array}{c}\text { Other } \\
\text { Dissolved Ions }\end{array}$ \\
\hline Bangladesh & $30 \times 10^{6}$ & $<0.5-2500$ & $\begin{array}{l}\text { Strongly reducing } \\
\text { conditions, neutral } \\
\text { pH, high alkalinity }\end{array}$ & High $\mathrm{Fe}$ \\
\hline West Bengal & $6 \times 10^{6}$ & $<10-3200$ & $\begin{array}{l}\text { As for Bangladesh } \\
(27 \%>50 \mu \mathrm{g} / \mathrm{L})\end{array}$ & High Fe \\
\hline China & $5.7 \times 10^{6}$ & $10-1820$ & $\begin{array}{l}\text { Strongly reducing } \\
\text { artesian conditions }\end{array}$ & \\
\hline $\begin{array}{l}\text { Argentina (Chaco } \\
\text { Pampean Plain) }\end{array}$ & $2 \times 10^{6}$ & $<1-5300$ & $\begin{array}{l}\text { Oxidizing conditions, } \\
\text { neutral-to-high } \mathrm{pH}, \\
\text { high alkalinity; } \\
\text { arsenic present mainly } \\
\text { as } \mathrm{As}(\mathrm{V}) \text {. }\end{array}$ & \\
\hline Mexico (Lagunera) & $0.4 \times 10^{6}$ & $8-620$ & $\begin{array}{l}\text { Oxidizing conditions, } \\
\text { neutral-to-high } \mathrm{pH} \text {; } \\
\text { arsenic present mainly } \\
\text { as } \mathrm{As}(\mathrm{V})\end{array}$ & $\begin{array}{l}\text { Low } \\
\text { concentrations } \\
\text { of dissolved } \mathrm{Fe} \\
\text { and } \mathrm{Mn}\end{array}$ \\
\hline $\begin{array}{l}\text { Northern Chile } \\
\text { (Antofagasta) }\end{array}$ & $0.5 \times 10^{6}$ & $100-1000$ & $\begin{array}{l}\text { Oxidizing conditions, } \\
\text { high pH; arsenic } \\
\text { present mainly as } \\
\text { As }(V)\end{array}$ & \\
\hline $\begin{array}{l}\text { Red River Delta, } \\
\text { Vietnam }\end{array}$ & $>10 \times 10^{6}$ & $1-3050$ & $\begin{array}{l}\text { Reducing conditions, } \\
\text { high alkalinity }\end{array}$ & $\begin{array}{l}\text { High } \\
\text { concentrations } \\
\text { of Fe, } \mathrm{Mn}, \mathrm{NH}_{4}\end{array}$ \\
\hline $\begin{array}{l}\text { USA river water, } \\
\text { baseline }\end{array}$ & - & 2.1 & -- & -- \\
\hline
\end{tabular}

${ }^{\mathrm{a}}$ From Reference 9. 


\section{OVERVIEW OF ARSENIC TREATMENTS}

Most arsenic treatments fall into four process categories: ion exchange, membrane process, adsorption, or chemical precipitation. Ion-exchange treatments are very limited in their ability to remove arsenic because of exchange competition from other anions found in groundwater. Membrane processes are very effective at removing arsenic from groundwater, but the cost is high. Accordingly, adsorption and chemical precipitation processes are being explored for low-cost, effective treatments (4).

\subsection{ADSORPTION AND CHEMICAL PRECIPITATION TREAMENTS}

Most adsorption and chemical precipitation treatments require an oxidation pretreatment to convert $\mathrm{As}(\mathrm{III})$ into $\mathrm{As}(\mathrm{V})$ because $\mathrm{As}(\mathrm{V})$ usually adsorbs and reacts more strongly than As(III). Arsenic can be oxidized by ozone, free chlorine, hypochlorite, permanganate, birmessite, manganese oxide, hydrogen peroxide and Fulton's reagent (4). Although ozone has a very high oxidation potential, it can lead to side reactions with natural organic matter (13). Using chlorine poses the risk of introducing harmful trichloromethane into the drinking water. The most common oxidizing reagents used in developing countries are atmospheric oxygen, hypochlorite $(\mathrm{HClO})$, and permanganate. Air oxidation is very slow compared with permanganate $\left(\mathrm{KMnO}_{4}\right)$ and chlorine, which can oxidize As(III) rapidly under a wide range of conditions (4). Permanganate is a very effective and stable oxidizing agent, but gives water an unattractive color, which can be removed by an adsorbing media such as sand (14).

Agents that can bind to arsenic through adsorption or through formation of insoluble compounds with arsenic by precipitation or co-precipitation are referred to as sorbents. Many kinds of sorbents have been tested in both laboratory and field studies. Those sorbents are too numerous to account for in this report, and thus only the most common ones that have undergone extensive laboratory and/or field tests are examined.

The present focus on arsenic remediation in third-world countries is on using ironcontaining compounds because they are both cheap and effective $(15,16)$. Other synthetic sorbents such as lanthanum compounds (17), manganese oxides (18), Aqua-bind ${ }^{\mathrm{TM}}$ (19), and granular ferric hydroxide (20) have also proved effective for arsenic removal. Clays and mineral-containing rocks are very capable of absorbing arsenic but often at a much slower rate $(11,16)$. Laboratory tests might show high arsenic removal results for many adsorbents, but experience show that the absorbents are not as effective in the field because of the presence of $\mathrm{Mg}^{2+}$ and $\mathrm{Ca}^{2+}$ and other naturally occurring ions, which compete with arsenic for adsorbent sites (21). The majority of the technologies discussed in this report have yet to be field-tested, and so the results from laboratory research indicate only their probable performance in the field.

\subsubsection{Ferric Salts and Aluminum Alum}

Coagulation-flocculation processes using alum, ferric chloride, or ferric sulfate are effective at removing arsenic. They are the most well known arsenic treatments and have been more extensively tested in both laboratory and field studies than other technologies. Since both alum and ferric salts are more efficient at removing arsenate, oxidation of As(III) is required to 
achieve maximum removal efficiency. On a weight basis, ferric salts are more efficient at removing arsenic than alum. Ferric salts are also effective in removing arsenic over a wider range of $\mathrm{pH}$ than alum (4).

Methodology: $\mathrm{KMnO}_{4}$ is added to water to oxidize As(III). Coagulants (ferric salts or alum) are then added, and the solution is stirred well for a few minutes. Microflocs begin forming rapidly as the solution is stirred gently to allow the formation of easily settable flocs. Finally, the arsenic adsorbed on coagulants is removed by sedimentation. A filtration step may be needed for complete removal of all flocs.

Laboratory Results: The Bucket Treatment Unit (BTU) developed by DPHE-Danita Project made use of the coagulation-flocculation process using ferric salts. The first bucket (both are $20 \mathrm{~L}$ ) was used for mixing chemicals, and the second one contained treated water. Field studies showed that by using $100 \mathrm{mg} / \mathrm{L}$ of ferric chloride and $1.4 \mathrm{mg} / \mathrm{L}$ of $\mathrm{KMnO}_{4}$, the arsenic content in treated water was well below $50 \mu \mathrm{g} / \mathrm{L}$ and never exceeded $37 \mu \mathrm{g} / \mathrm{L}$. The arsenic range in untreated water was between 375 and $640 \mu \mathrm{g} / \mathrm{L}$. Arsenic removal efficiency of ferric salts is often well over $90 \%$.

\subsubsection{Iron Filings}

Zerovalent iron $\left(\mathrm{Fe}^{\mathrm{o}}\right)$ has many important applications in environmental chemistry. It has been used to destroy chlorinated hydrocarbons and to remove inorganic contaminants, such as $\mathrm{CrO}_{4}{ }^{2-}$, via reductive precipitation. $\mathrm{Fe}^{\circ}$ has also proved effective at removing $\mathrm{As}(\mathrm{III})$ and $\mathrm{As}(\mathrm{V})$, and the predominant mechanistic pathways seems to be surface precipitation or adsorption (16). $\mathrm{Fe}^{\mathrm{o}}$ is a strong reducer and thus is an effective agent for removing both inorganic and organic arsenic. Another advantage of using $\mathrm{Fe}^{\mathrm{o}}$ is that it is nontoxic and inexpensive. Literature data show that $\mathrm{Fe}^{\mathrm{o}}$ is effective at removing $\mathrm{As}$ at low $\mathrm{pH}$ and in high-sulfide-containing water. Although the reducing strength of $\mathrm{Fe}^{\mathrm{o}}$ decreases significantly at neutral $\mathrm{pH}$, the hydroxide species forming on the surface of $\mathrm{Fe}^{\mathrm{o}}$ are effective adsorption sites for both $\mathrm{As}(\mathrm{V})$ and $\mathrm{As}(\mathrm{III})$ at neutral and basic $\mathrm{pH}(1)$.

\subsubsection{Ramaswami et al. Study}

Ramaswami et al. (10) investigated $\mathrm{Fe}^{\mathrm{o}}$ for arsenic removal using a batch-mixed iron treatment with zerovalent iron. High removal efficiency (93\%) was achieved for a short contact time (0.5-3 hours). Only As(III) species were tested, however. The highest rate of removal was found in headspace-free systems when sulfates were present in solution, whereas slower rates were found when phosphate was present because it tends to retard sorption uptake by iron. Arsenic was found to adsorb strongly to the iron filings, and the treated water could be easily decanted. Residual dissolved iron was at low concentrations that were safe for drinking water. The treatment was most appropriate for in-home point-of-use techniques. The iron could be reused at least 100 times. A treatment of $10 \mathrm{~L}$ of water per day for a year would cost a family in India or Bangladesh $\$ 0.60$, a reasonable charge.

Methodology: Only As(III) solutions were used in the study (10). The pH value in all vessels was maintained at 5 . Optimal conditions for arsenic removal were first determined by 
running a batch-mixed experiment with high-arsenic-content water $(2000 \mu \mathrm{g} / \mathrm{L})$. The conditions were then evaluated with water containing $200 \mu \mathrm{g} / \mathrm{L}$ to test the performance of the technology over a wide concentration range. Three sets of systems were evaluated for effectiveness at removing arsenic:

- Vessel containing arsenic, sulfate, and some natural minerals with no air present

- Vessel containing arsenic and sulfate with some air present

- Vessel containing arsenic and phosphate with some air present

Solid iron filings were added to the vials at both high $(2500 \mathrm{mg} / \mathrm{L})$ and low loadings $(1250 \mathrm{mg} / \mathrm{L}$ and $625 \mathrm{mg} / \mathrm{L}$ ). The vials were mixed, and a sample from each vial was collected for analysis.

Laboratory Results: Arsenic removal was not efficient in the presence of air and/or phosphates. The results from headspace-free systems (filled with water) show that high removal efficiency can be achieved over a wide range of arsenic concentrations using iron filings, while maintaining a low level of dissolved iron in water. A headspace-free system containing a highiron dose of $2,500 \mathrm{mg} / \mathrm{L}$ and an initial arsenic concentration of $2,000 \mu \mathrm{g} / \mathrm{L}$ can remove $95 \%$ of arsenic in 30 minutes. The final arsenic concentration was $120 \mu \mathrm{g} / \mathrm{L}$, and the amount of dissolved iron was below the regulatory limit. Smaller iron doses $(625 \mathrm{mg} / \mathrm{L}$ and $1250 \mathrm{mg} / \mathrm{L})$ in the same headspace-free system containing initial arsenic concentration of $2,000 \mu \mathrm{g} / \mathrm{L}$ showed $95 \%$ removal in 3 hours of contact time (compared with 30 minutes contact time with an iron dose of $2500 \mathrm{mg} / \mathrm{L})$. In contact with arsenic at low concentration $(200 \mu \mathrm{g} / \mathrm{L})$, solid iron $(625-$ $2500 \mathrm{mg} / \mathrm{L}$ ) can achieve $>90 \%$ arsenic removal efficiency while maintaining a safe level of dissolved iron in water. In another study where $\mathrm{BaSO}_{4}$ was added to promote the formation of arsenopyrites (22), a simple tube filled with sand and iron filings, designed to fit in a well outlet, can achieve $97 \%$ arsenic removal for initial arsenic concentration of $45-8600 \mu \mathrm{g} / \mathrm{L}$.

\subsubsection{Su and Puls Study}

Four types of zerovalent iron filings (Fisher, Peerless, Master Builders, and Aldrich) were investigated for removal of $\mathrm{As}(\mathrm{III})$ and $\mathrm{As}(\mathrm{V})$ from drinking water (16). The metals were allowed to react with arsenic, and relative removal efficiencies were achieved in the following order: Fisher $>$ Peerless, Master $>$ Aldrich. With the exception of Aldrich $\mathrm{Fe}^{\mathrm{o}}$, arsenic concentrations decreased exponentially with time in other $\mathrm{Fe}^{\mathrm{o}}$ solutions and were $<10 \mu \mathrm{g} / \mathrm{L}$ in four days.

Methodology: A 50-mL polypropylene tube (headspace-free) was filled with arsenic water $(2 \mathrm{mg} / \mathrm{L})$ containing $\mathrm{As}(\mathrm{V})$, As(III) or equal parts of $\mathrm{As}(\mathrm{III})$ and $\mathrm{As}(\mathrm{V})$ in $0.01 \underline{\mathrm{M} \mathrm{NaCl}}$. To these tubes, $1.0 \mathrm{~g}$ of $\mathrm{Fe}^{\mathrm{o}}$ was added and the solutions were mixed in a reciprocating shaker. The suspension was then centrifuged, and the resultant supernatant was filtered through a $0.1-\mu \mathrm{m}$ membrane and analyzed for arsenic content.

Laboratory Results: Arsenic concentrations decreased exponentially with time in all systems. The relative rate constants for the removal of $\mathrm{As}(\mathrm{III})$ and $\mathrm{As}(\mathrm{V})$ by $\mathrm{Fe}^{\mathrm{o}}$ were as follows: Fisher $>$ Peerless, Master $>$ Aldrich. With the exception of the Aldrich $\mathrm{Fe}^{\mathrm{o}}$, arsenic concentrations in the other three systems decreased to less than $0.010 \mathrm{mg} / \mathrm{L}$ within 96 hours. At 
$\mathrm{pH}$ above 7, As(III) was removed faster than $\mathrm{As}(\mathrm{V})$, whereas the rate constant for As(III) + $\mathrm{As}(\mathrm{V})$ was between the rates of $\mathrm{As}(\mathrm{III})$ and $\mathrm{As}(\mathrm{V})$. The sorption capacities were $730 \mathrm{mg} / \mathrm{kg}$ $\mathrm{As}(\mathrm{V})$ and $1770 \mathrm{mg} / \mathrm{kg} \mathrm{As}(\mathrm{III})$ for Peerless iron. An iron oxide layer could form on the surface of $\mathrm{Fe}^{\mathrm{o}}$ due to corrosion, and this layer was likely the predominant adsorption site for both As species.

\subsubsection{Gravel Bed Containing Iron-Coated Sand}

Methodology: Iron-coated sand was tested for As removal in glass burettes with sand bed depths of 20 and $40 \mathrm{~cm}$ (23). Groundwater spiked with both As(III) and As(V) was passed through the burettes, and the effluent was collected for analysis. Coating the sand with iron required washing it first with $20 \%$ commercial grade acid for 24 hours. After drying, the sand was mixed with $2 \underline{\mathrm{M}} \mathrm{FeNO}_{3}$ and $10 \mathrm{~N} \mathrm{NaOH}$. To every $200 \mathrm{~cm}^{3}$ of sand, the addition of $80 \mathrm{~mL}$ of ferric nitrate solution and $4 \mathrm{~mL}$ of $\mathrm{NaOH}$ solution was required. The mixture was then heated in an oven for 14 hours at $110^{\circ} \mathrm{C}$. Thereafter, the sand was thoroughly washed with distilled water.

Laboratory Results: For an arsenic concentration of $300 \mu \mathrm{g} / \mathrm{L}, 200$ to 225 bed volumes of groundwater could be treated using a $20-\mathrm{cm}$ sand bed before the arsenic content of the effluent reached breakthrough. With the $40-\mathrm{cm}$ sand bed, 350 to 400 bed volumes of water could be treated before breakthrough occurred. Contact time between arsenic-bearing water and ironcoated sand was about $1 \mathrm{~min}$ in the $20-\mathrm{cm}$ sand bed and $3 \mathrm{~min}$ in the $40-\mathrm{cm}$ bed. For the $40-\mathrm{cm}$ sand bed, the flow rate varied from 10 to $15 \mathrm{~mL} / \mathrm{min}$. Unlike the results found in coagulation experiments with ferric salts, both $\mathrm{As}(\mathrm{III})$ and $\mathrm{As}(\mathrm{V})$ species were removed indiscriminately. Hence, there was no need for preoxidation of As(III) using this treatment. Moreover, the sand could be regenerated after initial use with little reduction in its removal capacity.

\subsubsection{Gravel Bed Containing Iron Sludge}

Methodology: Iron sludge is a ferric hydroxide/water slurry containing ferric sulfate, ferrous sulfate and ferric chloride. It was prepared by changing the $\mathrm{pH}$ of the iron salt solution through the addition of sodium hydroxide. Iron sludge was then introduced onto gravel media (a straight plastic tube 1.5" long). Arsenic removal was evaluated by passing groundwater spiked with known amounts of arsenic through the media (23). Iron sludge was introduced onto the media in two ways: pouring down or passing through in an upflow mode.

Laboratory Results: Iron sludge did not adhere well to the gravel bed and was very sensitive to the flow rate of water passing through the gravel bed. Most of the iron sludge accumulated on top of the media. Arsenic removal efficiency was very low, with a maximum value of $50 \%$ at the initial arsenate concentration of $300 \mu \mathrm{g} / \mathrm{L}$. The main reason for low removal efficiency probably was the formation of flow channels through the iron sludge accumulated on top of the gravel bed. These flow channels reduced the contact time between arsenic-bearing groundwater and iron sludge. 


\subsubsection{Lanthanum Compounds}

Lanthanum is one of the cheapest rare-earth elements. Lanthanum hydroxide (LH), lanthanum carbonate (LC), and basic lanthanum carbonate (BLC) were investigated (17) for removing arsenate $(\mathrm{V})$ ion from aqueous solutions. Two proposed mechanisms for arsenic removal by lanthanum compounds are adsorption by exchange of $\mathrm{CO}_{3}$ and/or $\mathrm{OH}$ group with $\mathrm{As}^{5+}$ ions in the neutral-to-basic $\mathrm{pH}$ range when La does not dissolve, and precipitation of insoluble lanthanum arsenate, $\mathrm{LaAsO}_{4}$, in the acid $\mathrm{pH}$ range.

Methodology: A $100 \mathrm{~mL}$ solution of $0.25 \mathrm{mM} \mathrm{As}(\mathrm{V})$ was prepared at $\mathrm{pH}$ range 2-12. To this solution was added $0.10 \mathrm{~g}$ of La compound. The resultant solution was mixed at $20^{\circ} \mathrm{C}$, and an aliquot from the sample was collected at intervals and filtered with a $0.45-\mu \mathrm{m}$ membrane filter. The filtrate was then analyzed for La and As ions.

Laboratory Results: The dissolution of lanthanum compounds was appreciable at $\mathrm{pH}$ $<3.3,<4.3$ and $<4.0$ for $\mathrm{LH}, \mathrm{LC}$ and BLC, respectively. The highest As removal rates for LH, $\mathrm{LC}$ and BLC were found at initial $\mathrm{pH} 2.98,3.75$, and 3.01 respectively. The optimal initial $\mathrm{pH}$ for As removal was found at ranges 3-8, 4-7 and 2-4 for LH, LC and BLC, respectively. All lanthanum compounds could lower $\mathrm{As}(\mathrm{V})$ concentrations in aqueous solutions to below regulatory limits $(<0.001 \mathrm{mM})$.

LH removed $\mathrm{As}(\mathrm{V})$ ion fastest at a wider $\mathrm{pH}$ range (3-8) compared with other lanthanum compounds. In the initial $\mathrm{pH}$ range 2.98 to 6.99 , it took less than 4 hours to lower initial As(V) concentration to $<0.001 \mathrm{mM}$. LH could still remove most of $\mathrm{As}(\mathrm{V})$ at $\mathrm{pH} 8.75$, but at a much slower rate.

\subsubsection{Kimberlite Tailings}

Kimberlite tailings were investigated in batch studies for adsorption kinetics, equilibrium isotherm, and factors controlling its effectiveness at removing arsenic (24). Column studies were also conducted to investigate the performance of fixed-bed Kimberlite. This sorbent could remove $90-94 \%$ of arsenic from both tap water spiked with arsenic and from groundwater collected from various provinces in West Bangel, India. The batch studies provide the basis for designing column filters for low-cost, effective removal of arsenic.

Methodology: Kimberlite tailings particle sizes of 150-300 $\mu \mathrm{m}$ (geometric mean size $=$ $212 \mu \mathrm{m})$ and $300-500 \mu \mathrm{m}$ (geometric mean size $=387 \mu \mathrm{m})$ were used in the study. The particles were prepared as follows. Kimberlite tailings were first thoroughly cleaned with tap and distilled water. They were then dried, powdered, and sieved through 150-, 300- and 500-micron sieves. The sieve material was then washed thoroughly with tap and distilled water and dried at $100^{\circ} \mathrm{C}$ for 10 hours. After the dried material was cooled in a desiccator for 10 hours, it was sieved once more to the required size. The material was then stored in an air-tight bottle. The selected particles were used in the absorption experiment. An absorbent (geometric mean size, GMS = $0.212 \mathrm{~mm}$ ) dose of $20 \mathrm{~g} / \mathrm{L}$ was used to investigate isotherm equilibrium, adsorbent kinetics, and arsenic removal from groundwater collected from various parts of West Bangel. A column 
study was also carried out. Average flow rates $(10.13 \mathrm{~cm} / \mathrm{min})$ and arsenic concentrations in the influent $(1 \mathrm{mg} / \mathrm{L})$ were maintained throughout. The adsorbent was supported in the column by glass wool. Arsenic content in the effluent was periodically analyzed.

Laboratory Results: Batch tests showed that arsenic removal was dependent on $\mathrm{pH}$, and the highest removal efficiency was observed in the neutral $\mathrm{pH}$ range. Arsenic-saturated Kimberlite tailings can be regenerated with $0.2 \mathrm{~N} \mathrm{NaOH}$. Kinetic studies showed that pore diffusion was not the rate-limiting step, and film adsorption appeared to be the mechanism. Removal efficiency was found to be higher for smaller adsorbent size (more surface area sites for adsorption). Groundwater from eight affected districts in West Bangel were collected and tested for arsenic removal using the tailings. The treatment showed $90-94 \%$ removal in $12 \mathrm{~h}$ of contact time. In column studies, the breakthrough point of Kimberlite tailings was found at $0.27 \mathrm{mg} / \mathrm{g}$, about one-fourth that of activated alumina. While the capacity for arsenic removal of activated alumina is greater than that of Kimberlite tailing, activated alumina is much more expensive.

\subsubsection{Alumina Manganese Oxide}

Kepner et al. (21) tested alumina-metal oxide composite particles (Al-MOC) for arsenic removal and found that among the Al-MOCs, alumina-manganese oxide composite particles were most effective at removing arsenic.

Methodology: The enhanced hybrid aluminas (EHAs) were prepared by heating boehmite to $400^{\circ} \mathrm{C}$ and treating with acetic acid. Alumina-manganese oxide composite (AlMOC) particles were prepared by binding the EHAs and metal oxides using a proprietary colloidal alumina binder system. About $1 \mathrm{~g}$ of Al-MOC was tumbled with $495 \mathrm{~mL}$ of $50 \mathrm{ppm}$ arsenic solutions (very high levels) for 24 hours. The solutions were then filtered and analyzed for arsenic content. The effect of $\mathrm{pH}$ on arsenic removal was analyzed by changing the $\mathrm{pH}$ of arsenic solutions.

Laboratory Results: "Synthetic" well water, typical of groundwater found in West Bengal, was treated with alumina manganese oxide. It removed up to $94 \%$ of As with the groundwater at initial arsenic concentrations of $50 \mathrm{mg} / \mathrm{L}$. Alumina manganese oxide was most effective (removal percentage) when its manganese composition was greater than $10 \%$ in $\mathrm{pH} 7$ solution. Increasing manganese content greater than $10 \%$ had no effect on the removal capacity of alumina manganese oxide, however. Alumina manganese oxide was also effective at removing other toxic metals such as iron, cadmium, antimony, lead, and uranium from the well water.

\subsubsection{Activated Alumina}

Activated alumina can be used as a fixed adsorbent for arsenic removal. Since $\mathrm{Fe}^{2+}$, which often occurs in high concentrations in groundwater, is oxidized to insoluble $\mathrm{Fe}^{3+}$ when exposed to air, it is necessary to remove iron prior to passing groundwater through an activated alumina column to prevent fouling. Oxidation of As(III) is also necessary because As(III) adsorbs poorly to activated alumina. 
Methodology: Naturally occurring iron in groundwater is removed simply by aeration followed by flocculation and sedimentation. After macro-iron flocs settled out, $\mathrm{KMnO}_{4}$ was added to the supernatant to make sure all arsenic species were in the pentavalent form. The supernatant was sand-filtered to remove any remaining macro-iron flocs. The water was then passed through the column filled with activated alumina particles.

Laboratory Results: Field studies (14) operated by the project team in Bangladesh showed that the unit reduced arsenic concentrations from an initial range of $176-240 \mu \mathrm{g} / \mathrm{L}$ to $2.2-$ $7.5 \mu \mathrm{g} / \mathrm{L}$. One concern was that some sand filters became harbors for bacteria, but the cause was most likely unhygienic practices of the users. The cost for each unit is Tk. $1500(\sim 25.60)$, but a survey indicated that majority of people were willing to pay between Tk. $300(\sim \$ 5.10)$ and Tk. $500(\sim \$ 8.50)$.

\subsubsection{Zeolites}

Zeolites are an important group of minerals due to their catalytic, sieve, and exchange properties. They are naturally abundant and are potentially low-cost materials for arsenic removal. Six zeolites were tested for removal of arsenic from aqueous solutions (11). The primary focus in this research was the most common naturally occurring clinoptilolite-containing zeolite (ZMS, ZMT, and ZH types). Arsenic removal was also investigated with zeolitemodified with iron.

Methodology: ZMS, ZMT, and ZH clinoptilolite-bearing zeolites, ZS-M and ZME mordenite-containing zeolite, and erionite-containing ZMA were tested for arsenic removal. Their activation consisted of washing them with $2 \mathrm{M} \mathrm{HCl}$, followed by mixing, decantation, and drying. Sorption of arsenic by these solids was investigated in batch studies. The solutions were allowed to equilibrate and were initially shaken in an ultrasonic bath. Iron-modified zeolites were prepared by equilibrating the solids with $\mathrm{Fe}^{2+}$ solutions.

Laboratory Results: As(III) was simultaneously oxidized and removed. The resultant $\mathrm{As}(\mathrm{V})$ was subsequently sorbed by the zeolite. Both $\mathrm{As}(\mathrm{III})$ and $\mathrm{As}(\mathrm{V})$ were removed efficiently in the $\mathrm{pH}$ interval 4-11 after contact with zeolite $\mathrm{ZH}$ and ZMA for a few days. Residual arsenite and arsenate were $0-5 \mu \mathrm{g} / \mathrm{L}$ and $30-40 \mu \mathrm{g} / \mathrm{L}$, respectively. Erionite-bearing ZMA showed highest removal efficiency in the iron-modified group, and natural clinoptilolite ZMS showed highest removal efficiency in the unmodified group. Compared with conventional treatment using iron hydroxide, iron-modified mordenite ZM-M and ZMA removes As(III) up to $89 \%$ and $75 \%$, respectively, of the amount removed by conventional iron treatments.

\subsubsection{Fixed-Bed Upflow Bioreactors}

This technology (25) utilizes biological oxidation of Fe and Mn ions to remove arsenic from groundwater. The oxidized forms of these metals can be removed by transforming them into insoluble oxides and subsequent separation by a filter medium. Removing these metals would simultaneously remove arsenic because the resultant metal oxides are effective adsorbents for arsenic. Under optimal conditions, $97 \%$ of the metal oxides and up to $80 \%$ of arsenic can be removed. Since most physiochemical treatments for arsenic, such as coagulation, require the 
addition of oxidizing agents to oxidize As(III), this technology could be a low-cost alternative because it does not require such additives. The applied linear velocity afforded by this technology is often higher than in physicochemical treatments. Also, there is no need to monitor the breakthrough point because iron and manganese oxides are continuously produced in situ. Another advantage this technology has is that it removes all three contaminants- $\mathrm{Fe}, \mathrm{Mn}$, and As - in one treatment.

Methodology: Oxidizing bacteria (Gallionella ferrunginea and Leptothrix ochracea) were cultured as oxidizing sources for Fe and $\mathrm{Mn}$, respectively. During biological oxidation, iron and manganese oxides were deposited in a filter media. As arsenic water was passed through the filtering media, arsenic was removed by adsorption or coprecipitation with the iron and manganese oxides. The system was based on a two-stage upflow fixed-bed filtration unit preceded by a separate controlled aeration unit to maintain the bacteria.

Microorganisms were cultivated inside the columns. The groundwater flow was continuous and was mixed with As-spiked water just prior to passing into the aeration column. Air was injected to provide oxygen for the bacteria. The effluent was collected and samples were analyzed for As(III), total arsenic, and iron and manganese concentrations. Periodic backwashing (every 3 days) of the column was carried out to prevent clogging from the formed iron and manganese oxides. The experiment was carried out at $\mathrm{pH} 7.2$ and at linear velocity 8.25 $\mathrm{m} / \mathrm{h}$.

Laboratory Results: Iron was oxidized mainly by the bacteria under the following conditions: dissolved oxygen $=2.7 \mathrm{mg} / 1$, redox potential $=280-290 \mathrm{mV}$, and $\mathrm{pH}=7.2$. Residual iron and manganese were always found below regulatory limits $(0.2 \mathrm{mg} / \mathrm{L}$ for Fe and $10 \mathrm{mg} / \mathrm{L}$ for $\mathrm{Mn}$ ). Arsenic (both trivalent and pentavalent form) was removed mainly in the first filtration unit by adsorption on iron oxides. The linear velocity was kept constant throughout at $8.25 \mathrm{~m} / \mathrm{hr}$. Highest arsenic removal efficiency (80-84\%) was achieved at an initial arsenic concentration range of $35-80 \mu \mathrm{g} / \mathrm{L}$ and under a linear velocity range of $7-14 \mathrm{~m} / \mathrm{hr}$. The removal efficiency slightly decreased when the initial arsenic concentration was $>80 \mu \mathrm{g} / \mathrm{L}$.

\subsubsection{Soyatal Formation}

Soyatal Formation, an abundant clay-rich limestone in the Zimapan Mining District of Mexico, was used to extract arsenic from groundwater (26). Soyatal Formation contains kaolinite and illite in its calcareous shale, and these minerals are known to adsorb arsenic efficiently.

Methodology: Native water samples were collected from wells and groundwater sources in the region. Soyatal Formation was collected along the road between El Detzani and El Dedho in Cerro del Morro. The rocks of the Soyatal Formation were crushed to pea size and then powdered using a shatterbox. Arsenic removal potential and optimal conditions for removal were investigated through batch reactions. After frequent shaking of the solutions containing arsenic and rock, the particles were allowed to settle. Safe drinking water could be obtained by filtering the fluid through several layers of cloth. 
Laboratory Results: The results demonstrated that an increase in reaction time, rockwater ratio, and shaking frequency would result in an increase in arsenic removal. Continuous shaking using a wrist-shaker for 12 hours decreased initial arsenic concentration from $768 \mu \mathrm{g} / \mathrm{L}$ to an average of $55 \mu \mathrm{g} / \mathrm{L}$, a $93 \%$ removal efficiency. The highest removal efficiency for powdered rock at a $1: 5$ rock:water ratio was $87 \pm 5 \%$, whereas the highest removal efficiency for crushed rock was $91 \% \pm 5 \%$ at rock:water ratios of 1:2, 1:10, and 1:20. Water having a 1:5 rock:water ratio tasted salty, whereas water having 1:10 rock:water ratio tasted normal.

\subsubsection{Manganese Greensand}

Manganese greensand is a zeolite-type glauconite mineral, artificially coated with a layer of active hydrous manganese dioxide and other high oxides of Mn (7).

Methodology: Manganese greensand was prepared by treating the glauconite sand with $\mathrm{KMnO}_{4}$. The greensand produced was a granular material, coated with a layer of active hydrous manganese dioxide and other high oxides of $\mathrm{Mn}$. Greensand $\left(0.005 \mathrm{~m}^{3}\right), \mathrm{KMnO}_{4}(10 \mathrm{~g})$, and water $(972 \mathrm{~mL})$ were added to a column to condition the material. Tap water spiked with As(III) $(200 \mu \mathrm{g} / \mathrm{L})$ was used for all tests. Arsenic water was pumped into the column filter and the effluent was collected for analysis. $\mathrm{KMnO}_{4}$ was continuously added to generate the column and to oxidize the $\mathrm{Fe}(\mathrm{II}), \mathrm{Mn}(\mathrm{II})$ and As(III). Amberlite IR-120 cation exchange resins and ironoxide-coated sand were also tested for arsenic removal and were compared with manganese greensand for effectiveness.

Laboratory Results: In the presence of iron (Fe:As ratio $=20: 1$ ), manganese greensand was more effective at removing arsenic than iron-oxide-coated sand and resin. Arsenic removal of $81.8 \%$ was achieved from an initial arsenic concentration of $100 \mu \mathrm{g} / \mathrm{L}$. The initial solution $\mathrm{pH}$ was neutral and was not adjusted throughout the tests.

\subsubsection{Goethite}

Goethite is an $\alpha$-iron(III) hydroxy-oxide mineral $[\mathrm{FeO}(\mathrm{OH})]$ and is the most stable form of iron oxide in soil. Synthetic goethite particles were investigated (27) for removal of As(V) from dilute aqueous solutions. The small size of the particles necessitated an efficient solid/liquid separation technique.

Methodology: A solution of $1 \mathrm{~g} / \mathrm{L}$ goethite, $10 \mu \mathrm{g} / \mathrm{L} \mathrm{As}(\mathrm{V})$, and $0.1 \mathrm{mg} / \mathrm{L}$ polyelectrolyte was magnetically stirred for $30 \mathrm{~min}$ at $300 \mathrm{~K}$. Following flocculation, the dispersion was settled for 15 minutes and a sample was analyzed for residual turbidity. The average size of the goethite particles was $2.5 \mu \mathrm{m}$ in diameter.

Laboratory Results: Goethite particles are stable at $\mathrm{pH} 4-9$. Outside that $\mathrm{pH}$ range, the particles become unstable and begin releasing soluble ferric ions into solution. Wet goethite form (a paste) was found to have higher adsorption capacity than the dry form and was used throughout. $\mathrm{As}(\mathrm{V})$ was removed almost completely from the solution up to $\mathrm{pH} 6$. When ionic strength was raised, very high arsenic removal efficiency (>95\%) was achieved up to $\mathrm{pH} 9$. Although increasing ionic strength can facilitate arsenic removal, the quality of water was low at 
$\mathrm{pH}>5$ due to high residual turbidity. Ionic strength does not play a significant role in removing arsenic at lower $\mathrm{pH}$. Goethite particles sizes were found smaller (thus more adsorption capacity) at low $\mathrm{pH}$ and larger at $\mathrm{pH} 5$ and above. Larger and more stable flocs of goethite can be achieved by adding alum or ferric chloride to the solution. Dissolution of $\mathrm{FeAsO}_{4}$ increased at $\mathrm{pH}$ value greater than 5, and $\mathrm{FeAsO}_{4}$ can decompose at $\mathrm{pH}$ greater than 6 .

\subsubsection{Granular Ferric Hydroxide}

Technical University of Berlin introduced a new adsorbent, granular ferric hydroxide (Adsorpas ${ }^{\circledR}$ ), poorly crystallized $\alpha-\mathrm{FeOOH}$. In a review of selected arsenic technologies (20), Pal concluded that granular ferric hydroxide is a superior adsorbent because it meets four important criteria: high removal efficiency, safety, simple operation, and minimum residual mass. Pal quoted results from studies claiming removal efficiency of Adsorpas ${ }^{\circledR}$ being 5 to 10 times higher than that of activated alumina (20) and capacity of $45 \mathrm{mg} / \mathrm{g}^{\circ} \mathrm{AsO}_{4}{ }^{-}\left(0.32 \mathrm{mmol}^{-}\right.$ As/g). Adsorpas ${ }^{\circledR}$ is effective at a wide $\mathrm{pH}$ range (5.5 to 9), although there is a slight decrease in adsorption capacity with $\mathrm{pH}$.

Methodology: Arsenic is removed through a process using granular ferric hydroxide reactors, which are fixed-bed adsorbers that operate similarly to conventional filters with a downward water flow. The process consists of coagulation-filtration step with fixed-bed adsorption, and it can be used for both large-scale and small-scale applications.

The system is easy to make since it consists of only a gravel filter and an adsorption tower. Water first passes down a gravel filter (iron and suspended particles are removed), and second through an adsorption tower, where arsenic will be decreased to a safe level. The system is very self-sufficient since there is no need to adjust or maintain it around the clock as is the case with the precipitation and flocculation methods. Disposal of Adsorpas ${ }^{\circledR}$ is not problematic since it is non-toxic and non-hazardous and the authors claim that As does not leach from it.

Laboratory Results: The ferric hydroxide material handled 40,000-60,000 bed volumes of natural groundwater containing $21 \mu \mathrm{g} \mathrm{As} / \mathrm{L}$ before the $10 \mu \mathrm{g} / \mathrm{L}$ regulatory limit (Germany) was exceeded. The residual mass of hydroxide was $5-25 \mathrm{~g} / \mathrm{m}^{3}$ of treated water.

\subsubsection{Manganese-Coated Sand}

Manganese dioxide $\left(\delta-\mathrm{MnO}_{2}\right)$ can both oxidize As(III) and adsorb As(V). A media of manganese dioxide was prepared (28) using manganese-dioxide-coated sand. Groundwater was passed through the coated-sand media, and the arsenic content in the effluent was measured. The data showed very good arsenic removal; however, this was a limited experiment because important variables such as $\mathrm{pH}$ and competing anions were not investigated.

Methodology: Manganese dioxide was prepared in the presence of sand from the oxidation of manganous ion by permanganate. Initially $250 \mathrm{~g}$ of river sand was added in a $\mathrm{KMnO}_{4}$ solution. $\mathrm{NaOH}$ solution was then added to neutralize the acid and to keep the solution basic. A $0.3 \mathrm{M} \mathrm{MnCl}_{2}$ solution was introduced into the sand mixture dropwise while stirring with a magnetic stirrer. The mixture was then dried in an oven at $105^{\circ} \mathrm{C}$ for 24 hours. The dried 
sand was washed with distilled water until the after-wash water was clear. Finally, the sand was dried overnight at $10^{\circ} \mathrm{C}$ and stored in a capped bottle.

One of two chambers made of a galvanized iron sheet was placed on top of the other. The top chamber contained $4 \mathrm{~L}$ of manganese-dioxide-coated sand. A small orifice at the base of the top chamber controlled the flow rate at about $6 \mathrm{~L} / \mathrm{hr}$. The bottom chamber had a tap near its base. Seven liters of groundwater (spiked with $0.5 \mu \mathrm{g} / \mathrm{L} \mathrm{As}^{3+}$ and $0.5 \mu \mathrm{g} / \mathrm{L} \mathrm{As}^{5+}$ ) was placed in the top chamber and passed through the bottom one. The groundwater was allowed to pass until the arsenic content in the effluent exceeded $0.01 \mu \mathrm{g} / \mathrm{L}$ (a cycle). Between each cycle, the medium was regenerated in situ by washing it with $10 \mathrm{~L}$ of $0.2 \mathrm{~N} \mathrm{NaOH}$ until the influent and effluent $\mathrm{pH}$ were comparable.

Laboratory Results: A total of $740 \mathrm{~L}$ of water was produced before the arsenic content in the effluent reached undesirable levels. The amount of water produced was $700 \mathrm{~L}$ in the second cycle, a little less than the first cycle. It was found that water spiked with As(III) or a mixture of $\mathrm{As}(\mathrm{III})$ and $\mathrm{As}(\mathrm{V})$ had a much greater removal efficiency than water spiked with $\mathrm{As}(\mathrm{V})$ alone. Material and fabrication costs for the whole unit are $\$ 5$; the medium is $\$ 2$, and regeneration costs $\$ 0.13$, which is considered reasonable.

\subsubsection{Hydrotalcite $\left(\mathrm{Mg}-\mathrm{Al}-\mathrm{CO}_{3}{ }^{2-}\right)$}

Hydrotalcite-like materials are sorbants that can remove anions. Since the sorbants are in powder form, they pose problems in the solid/liquid separation process following the sorption stage. Sorption combined with separation by flotation was investigated (29), and the results showed effective solid/liquid separation and satisfactory removal of arsenic by hydrotalcite.

Methodology: Synthetic hydrotalcites (HT) were prepared by calcining $\mathrm{Mg}-\mathrm{Al}-\mathrm{CO}_{3}{ }^{2-}$ at $500^{\circ} \mathrm{C}$ for 10 hours. The HT was then added to a spiked $\operatorname{As}(\mathrm{V})$ solution $(20 \mathrm{mg} / \mathrm{L})$. The experiments were conducted in a dispersed-air flotation environment and various nonthioionisable surfactants were used in the flotation process.

Laboratory Results: The efficiencies of both $\mathrm{As}(\mathrm{V})$ removal and downstream flotation recovery were well over $90 \%$ at natural $\mathrm{pH}$ (initial arsenic concentration 20,000 $\mu \mathrm{g} / \mathrm{L}$ ). Arsenic removal was most effective at high ionic strength.

\subsubsection{Mesoporous Anion Trap (Cu-EDA-Si)}

Selective binding of anions is a great challenge in chemistry, biology, and materials and environmental sciences. $\mathrm{Cu}-\mathrm{EDA}-\mathrm{Si}$, a synthetic metal-chelated ligand immobilized on mesoporous silica, was used (30) as an anion binding material. The binding begins with electrosteric coordination, followed by displacement of one ligand and direct binding with the $\mathrm{Cu}(\mathrm{II})$ center.

Methodology: Mesoporous silica materials were first synthesized with cetyltrimethylammonium chloride/hydroxide (surfactant), tetramethylammonium silicate, HiSil silica powders, sodium aluminate, and mesitylene solutions, and then functionalized with ethylenediamine 
(EDA)-terminated silane. Then, they were hydrated and coated with EDA-terminated silane coatings. The functionalized silica was then stirred in a copper (II) chloride solution for a few hours to produce $\mathrm{Cu}-\mathrm{EDA}-\mathrm{Si}$.

Laboratory Results: With a solution $(\mathrm{mL})$ to sorbent $(\mathrm{g})$ ratio of 100 , nearly complete arsenic and chromate removal was achieved. Initial arsenic (V) concentration was very high, ranging from 1000 to $500,000 \mu \mathrm{g} / \mathrm{L}$, and the resin capacity was $1 \mathrm{mmol} \mathrm{As} / \mathrm{g}$. Anion competition was investigated using $\mathrm{SO}_{4}$; no significant effects were found, but chromate was found to be more specifically bound than arsenate.

\subsubsection{Clay Minerals (Kaolinite and Ilite)}

Methodology: Kaolinite and ilite were obtained from Washing County, Georgia, and Silver Hill, Montana, respectively. Batch experiments were conducted by shaking clay suspensions in $40-\mathrm{mL}$ polycarbonate centrifuge tubes containing $500 \mathrm{mg}$ of clay in $20 \mathrm{~mL}$ of $0.4 \mu \mathrm{M}$ As(III) or As(V) solution for $16 \mathrm{~h} \mathrm{(31).} \mathrm{The} \mathrm{pH}$ and ionic strengths also were investigated for optimal arsenic removal capability. After 16 hours of contact time, the tubes were centrifuged followed by filtering with a $0.1-\mu \mathrm{m}$ Whatman cellulose nitrate membrane. The supernatant was analyzed for residual arsenic concentrations.

Laboratory Results: Ionic strength had minor effects on the adsorption of arsenic to clay minerals. The adsorption of As(III) was low at low $\mathrm{pH}$, and maximum As(III) adsorption capacity for both minerals was between $\mathrm{pH} 7.5$ and 9.5. As(V) was removed most efficiently. Approximately $90-99 \%$ of $\mathrm{As}(\mathrm{V})$ was removed by both kaolinite and ilite at pH 6-8.8.

\subsubsection{Aqua-Bind ${ }^{\mathrm{TM}}$}

Aqua-Bind $^{\mathrm{TM}}$ consists of highly activated hybrid aluminas and alumina composites (19). An arsenic treatment unit (ATU) based on this technology was developed and field-tested (19). Demonstration units have been operating in India for 3 years and others are operating in Bangladesh. The results show a reduction of As from as much as $3500 \mu \mathrm{g} / \mathrm{L}$ to $<10 \mu \mathrm{g} / \mathrm{L}$ in a wide range of redox and arsenic concentrations. Best of all, this technology can remove arsenic within seconds and is highly selective because it is designed to remove only As(III) and As(V). The ATU is simple to use, easy to maintain, and relatively cheap, if mass-produced. Moreover, it is nontoxic and resistant to bacterial growth and poses no health or disposal concerns. The units are designed to be backwashed every couple of weeks and replaced after six months.

\subsubsection{Calcium Oxide}

Field experiments (32) on arsenic removal by calcium oxide were conducted at Goneshampur Village from November 2000 to March 2001. Calcium oxide was added to untreated water in different doses. The mixture was then allowed to settle for several hours in a container. Laboratory results showed that adding $0.1 \%$ (by weight) of lime to contaminated water reduced arsenic to safe levels after a settling time of 10 hours. After 16 hours, no arsenic was detected. 


\subsubsection{Wood Charcoal}

Contaminated water was passed through a unit (32) made of three pitchers (11 L each) at a controlled rate. The top pitcher, having a small orifice at the bottom, contained contaminated groundwater, and the middle pitcher contained layers of wood charcoal and sand. There was a small orifice in the middle container to prevent sand from leaking out. The last pitcher was used to collect treated water. About $97-99 \%$ removal efficiency was observed when $4480 \mathrm{~g}$ of sand and 606,754 or $757 \mathrm{~g}$ of charcoal were used, with the flow rate varying from 12 to $54 \mathrm{~mL} / \mathrm{min}$.

\subsubsection{Laterite}

Laterite is vesicular clay residuum that is abundant in tropical regions. It is composed mainly of hydrous oxides of iron and aluminum. Laboratory tests (22) showed that removal efficiency was in the range of $50-90 \%$ for $5 \mathrm{~g}$ of added laterite per $100 \mathrm{~mL}$ water after undergoing equilibrium for 20 minutes. Increased adsorption capacity of laterite was found when it was treated with $0.01 \underline{\mathrm{M}} \mathrm{HNO}_{3}$.

\subsubsection{Birnessite}

Synthetic birnessite $\mathrm{MnO}$ is representative of many naturally occurring manganese oxide materials, which are noted for their oxidizing potential. The $\mathrm{O} / \mathrm{Mn}$ ratio for most synthetic birnessite is 2. In this study (18), reactions of $\mathrm{As}(\mathrm{III})$ and $\mathrm{As}(\mathrm{V})$ with synthetic bimessite were evaluated for arsenic removal potential. The results indicated that $\mathrm{MnO}_{2}$ oxidized As(III) and the resultant $\mathrm{As}(\mathrm{V})$ was removed through adsorption to the $\mathrm{MnO}_{2}$ solid phase. Further analysis showed that oxidation of $\mathrm{As}(\mathrm{III})$ by $\mathrm{MnO}_{2}$ created more reaction sites on $\mathrm{MnO}_{2}$ surfaces for sorbing $\mathrm{As}(\mathrm{V})$. Synthetic birnessite proved to be an efficient oxidant for As(III), although birnessite removes only about $20-30 \%$ of $\mathrm{As}(\mathrm{V})$.

Methodology: $\mathrm{As}(\mathrm{III})$ and $\mathrm{MnO}_{2}$ were mixed in a rotating, propeller-stirred reactor in a temperature-controlled bath $\left(22^{\circ} \mathrm{C}\right)$ at $\mathrm{pH} 6.5$.

Laboratory Results: The results showed that $\mathrm{MnO}_{2}$ was a very efficient oxidizing agent. Dissolved As(III) in $250 \mathrm{mg} / \mathrm{L} \mathrm{MnO}_{2}$ was found below detection limits after 1 hour. Adsorption within the $\mathrm{MnO}_{2}$ removed $20-30 \%$ of $\mathrm{As}(\mathrm{V})$.

\subsubsection{Read-F}

Read-F is a new adsorbent recently introduced by Shin Nihon Salt Co. Ltd, Japan (4). It can remove arsenic in a wide range of conditions and shows great selectivity for both arsenite and arsenate without the need of pretreatment. The chemical composition of Read-F is ethylenevinyl alcohol copolymer (EVOH)-borne hydrous cerium oxide (4).

\subsubsection{Anion Exchangers}

Korngold et al. (33) used a transparent column loaded with strong-base anion-exchange resins (Purolite A-505 and Relite-A-490) to investigate adsorption of arsenic anions by the resin. 
Laboratory results showed that strong-base anion-exchanger resin could remove $>99 \%$ of arsenic from drinking water. The column could be regenerated with either $\mathrm{HCl}$ or $\mathrm{NaCl}$. The treatment was very inefficient in the presence of phosphate, chloride, and other anions at high concentrations. Therefore, low salinity $(<1000 \mathrm{TDS})$ is a prerequisite for effective arsenic removal. Relite-A-490 was more selective for $\mathrm{H}_{2} \mathrm{AsO}_{4}$ and $\mathrm{HAsO}_{4}{ }^{2-}$ and more effective at removing arsenic than Purolite A-505 and had higher breakthrough limits.

\subsection{ARSENIC WASTE DISPOSAL}

Arsenic waste can be disposed of by converting it into volatile organic forms through the activities of the microbes in soil or sediments. One such disposal method was used in Bangladesh where arsenic waste was disposed in soil in the backyard with cow dung added. Das et al. claim that the microbes residing in the cow dung helped convert arsenic into volatile arsenic species (34) since analyses of the soil failed to produce concentrated As values. This result appears dubious and it is worth noting that disposal of arsenic-rich residues is rarely addressed in the literature.

Table 3 summarizes the technologies reviewed here. 
Table 3. Summary of Technologies Reviewed

\begin{tabular}{|c|c|c|c|c|c|c|c|c|c|}
\hline Sorbent & $\begin{array}{c}\text { Amount of } \\
\text { Sorbant Used }\end{array}$ & $\begin{array}{l}\text { Range of } \\
\text { Arsenic } \\
\text { Tested }\end{array}$ & Efficiency & $\begin{array}{l}\text { Reaction } \\
\text { Time }\end{array}$ & $\begin{array}{c}\text { Arsenic } \\
\text { Species } \\
\text { Tested }\end{array}$ & pH & Advantage & Disadvantage & $\begin{array}{l}\text { Work } \\
\text { Cited }\end{array}$ \\
\hline Aqua-Bind $^{\mathrm{TM}}$ & & $\begin{array}{c}152- \\
3500 \mu \mathrm{g} / \mathrm{L}\end{array}$ & Almost $100 \%$ & $15 \mathrm{sec}$ & Both & Wide range & $\begin{array}{l}\text { Cheap; no } \\
\text { pretreatment; high } \\
\text { selection for both } \\
\text { As(III+V); rapid } \\
\text { kinetics }\end{array}$ & None & $(19)$ \\
\hline Ferric chloride & $\begin{array}{c}100 \mathrm{mg} / \mathrm{L} \text { of } \\
\text { ferric chloride } \\
\text { and } 1.4 \mathrm{mg} / \mathrm{L} \\
\text { of } \mathrm{KMnO}_{4}\end{array}$ & $\begin{array}{c}375- \\
640 \mu \mathrm{g} / \mathrm{L}\end{array}$ & $\begin{array}{l}>90 \% \text {, often } \\
95 \% \text { or more }\end{array}$ & $15 \mathrm{~L} / \mathrm{min}$ & $\begin{array}{l}\text { Both + } \\
\text { oxidation }\end{array}$ & Wide range & $\begin{array}{l}\text { Effective at a wide } \\
\text { range of } \mathrm{pH} ; \\
\text { arsenic } \\
\text { occurrence } \\
\text { correlates best } \\
\text { with Fe; low cost, } \\
\text { simple operation, } \\
\text { common } \\
\text { chemicals (4) }\end{array}$ & $\begin{array}{l}\text { Preoxidation, } \\
\text { filtration may be } \\
\text { needed to remove } \\
\text { all flocs; water } \\
\text { should not have } \\
\text { high silicate or } \\
\text { phosphate } \\
\text { concentrations } \\
\text { (27) }\end{array}$ & (4) \\
\hline Aluminum alum & $20 \mathrm{mg} / \mathrm{L}$ & $0.1 \mathrm{mg} / \mathrm{L}$ & $96 \%$ & $6 \mathrm{~h}$ & Both & pH 6.6 & $\begin{array}{l}\text { Low cost, simple } \\
\text { operation, } \\
\text { common } \\
\text { chemicals (4) }\end{array}$ & $\begin{array}{l}\text { Toxic waste } \\
\text { (sludges); } \\
\text { pre-oxidation } \\
\text { required for high } \\
\text { removal efficiency } \\
\text { (4); less soluble } \\
\text { than } \mathrm{FeCl}_{3}(27)\end{array}$ & (4) \\
\hline Read-F & & & Very efficient & Brief & Both & & High selectivity & $\begin{array}{l}\text { Adsorbent not as } \\
\text { effective at high } \\
\text { iron } \\
\text { concentrations }\end{array}$ & (4) \\
\hline $\begin{array}{l}\text { Iron filings type } \\
\text { (Su and Puls } \\
\text { study) }\end{array}$ & $1 \mathrm{~g}$ & $2 \mathrm{mg} / \mathrm{L}$ & $99 \%$ & 4 days & Both & 7 and above & $\begin{array}{l}\text { Cheap } \\
\text { Very simple to use } \\
\text { Nontoxic }\end{array}$ & $\begin{array}{l}\text { Not effective in } \\
\text { presence of } \\
\text { phosphate; } \\
\text { effective in } \\
\text { presence of } \\
\text { sulfate }\end{array}$ & $(16)$ \\
\hline $\begin{array}{c}\text { Iron filings } \\
\text { (Ramaswami et } \\
\text { al. study) }\end{array}$ & $2000 \mathrm{mg} / \mathrm{L}$ & $\begin{array}{c}200-2000 \\
\mu \mathrm{g} / \mathrm{L}\end{array}$ & $95 \%$ & $30 \mathrm{~min}$ & $\mathrm{As}(\mathrm{III})$ & $\mathrm{pH} 7$ & Very cheap & $\begin{array}{l}\text { Not effective in } \\
\text { presence of } \\
\text { phosphate }\end{array}$ & $(10)$ \\
\hline $\begin{array}{l}\text { Manganese } \\
\text { coated sand }\end{array}$ & $\begin{array}{l}4 \mathrm{~L} \text { of coated } \\
\text { sand }\end{array}$ & $500 \mu \mathrm{g} / \mathrm{L}$ & $\begin{array}{l}\text { Breakthrough } \\
=740 \mathrm{~L} \text { in first } \\
\text { cycle }\end{array}$ & $6 \mathrm{~L} / \mathrm{h}$, column & Both & $\begin{array}{l}\text { Bangladesh } \\
\text { water } \mathrm{pH} ; \\
\text { wide } \\
\text { distribution }\end{array}$ & $\begin{array}{l}\text { Very cheap; no } \\
\text { oxidation required }\end{array}$ & Complicated & (28) \\
\hline $\begin{array}{l}\text { Alumina } \\
\text { manganese } \\
\text { oxide }\end{array}$ & $1 \mathrm{~g}$ & $50 \mathrm{ppm}$ & $94 \%$ & $24 \mathrm{~h}$ & $\mathrm{As}(\mathrm{III})$ & $\begin{array}{l}\text { Range } 5.5-8, \\
\text { most effective } \\
\text { at } 7\end{array}$ & $\begin{array}{l}\text { "Self protecting" } \\
\text { from Mg and Ca; } \\
\text { also effective at } \\
\text { removing other } \\
\text { toxic metals }\end{array}$ & Long contact time & $(21)$ \\
\hline $\begin{array}{l}\text { Kimberlite } \\
\text { Tailings }\end{array}$ & $20 \mathrm{~g} / \mathrm{L}$ & $1 \mathrm{mg} / \mathrm{L}$ & $90-94 \%$ & $8-12 \mathrm{~h}$ & $\mathrm{As}(\mathrm{III})$ & $\begin{array}{c}\text { Acidic to } \\
\text { neutral pH (7) }\end{array}$ & $\begin{array}{l}\text { Cheap; no } \\
\text { oxidation required }\end{array}$ & $\begin{array}{l}\text { Slightly less } \\
\text { effective at } \mathrm{pH}>7\end{array}$ & $(24)$ \\
\hline
\end{tabular}


Table 3. Summary of Technologies Reviewed

\begin{tabular}{|c|c|c|c|c|c|c|c|c|c|}
\hline Sorbent & $\begin{array}{l}\text { Amount of } \\
\text { Sorbant Used }\end{array}$ & $\begin{array}{l}\text { Range of } \\
\text { Arsenic } \\
\text { Tested }\end{array}$ & Efficiency & $\begin{array}{l}\text { Reaction } \\
\text { Time }\end{array}$ & $\begin{array}{l}\text { Arsenic } \\
\text { Species } \\
\text { Tested }\end{array}$ & $\mathrm{pH}$ & Advantage & Disadvantage & $\begin{array}{l}\text { Work } \\
\text { Cited }\end{array}$ \\
\hline $\begin{array}{l}\text { Lanthanum } \\
\text { Hydroxide }\end{array}$ & $0.10 \mathrm{~g}$ & $0.25 \mathrm{mM}$ & $\begin{array}{l}\text { Lower arsenic } \\
\text { to well below } \\
\text { safe limit }\end{array}$ & $\begin{array}{c}\text { Most rapid at } \\
\mathrm{pH} 3-6.99, \\
>1 \text { day } \\
\text { contact time } \\
\text { for } \mathrm{pH}>8.75\end{array}$ & $\mathrm{As}(\mathrm{V})$ & $3-8$ & Cheap, simple & $\begin{array}{l}\text { Long contact time } \\
\text { at high } \mathrm{pH}\end{array}$ & $(17)$ \\
\hline $\begin{array}{l}\text { Fixed-bed } \\
\text { upflow } \\
\text { bioreactor }\end{array}$ & Fixed bed & $30-60 \mu \mathrm{g} / \mathrm{L}$ & $80 \%$ & $7-14 \mathrm{~m} / \mathrm{h}$ & Both & $\mathrm{pH} 7.2$ & $\begin{array}{l}\text { No need for pre- } \\
\text { oxidation; Fe, Mn, } \\
\text { As can be } \\
\text { removed }\end{array}$ & $\begin{array}{l}\text { Somewhat } \\
\text { elaborate process; } \\
\text { low arsenic } \\
\text { capacity }\end{array}$ & $(25)$ \\
\hline $\begin{array}{l}\text { Activated } \\
\text { alumina }\end{array}$ & Fixed bed & $\begin{array}{c}170-240 \\
\mu \mathrm{g} / \mathrm{L}\end{array}$ & $\sim 98 \%$ & & $\mathrm{As}(\mathrm{V})$ & $\begin{array}{l}\text { Bangladesh } \\
\text { water tested }\end{array}$ & & & (14) \\
\hline $\begin{array}{l}\text { Granular ferric } \\
\text { hydroxide }\end{array}$ & Fixed bed & $\begin{array}{l}\text { Huge } \\
\text { adsorbent } \\
\text { capacity }\end{array}$ & $>95 \%$ & & Both & $5.5-9$ & $\begin{array}{l}\text { Safe technology, } \\
\text { toxic-free waste, } \\
\text { simple operation } \\
\text { and little } \\
\text { maintenance }\end{array}$ & $\begin{array}{l}\text { Iron pretreatment } \\
\text { needed to avoid } \\
\text { clogging of filter } \\
\text { bed (4) }\end{array}$ & $(20)$ \\
\hline $\begin{array}{c}\text { Anion- } \\
\text { exchangers }\end{array}$ & $100 \mathrm{ml}$ of resin & $600 \mu \mathrm{g} / \mathrm{L}$ & $99 \%$ removal & $20 \mathrm{bed} \mathrm{vol} / \mathrm{h}$ & $\begin{array}{l}\text { Only } \\
\mathrm{As}(\mathrm{V})\end{array}$ & Tap water $\mathrm{Ph}$ & $\begin{array}{l}\text { Very high As }(\mathrm{V}) \\
\text { removal }\end{array}$ & $\begin{array}{l}\text { Sulfate and nitrate } \\
\text { exchange before } \\
\text { arsenic (4); TDS, } \\
\text { selenium, and } \\
\text { fluoride can also } \\
\text { decrease life of } \\
\text { resin (21) }\end{array}$ & (33) \\
\hline $\begin{array}{l}\text { Illite clay } \\
\text { minerals }\end{array}$ & $\begin{array}{l}1: 40 \text { rock:water } \\
\text { ratio }\end{array}$ & $\begin{array}{c}.4 \mu \mathrm{M} \mathrm{As}(\mathrm{III}) \\
\text { and } .4 \mu \mathrm{M} \\
\mathrm{As}(\mathrm{V})\end{array}$ & $\begin{array}{c}80 \% \text { for } \\
\text { As(III), 90- } \\
100 \% \text { for } \\
\mathrm{As}(\mathrm{V})\end{array}$ & $16 \mathrm{~h}$ & $\begin{array}{c}\text { Both } \\
\text { As(V) and } \\
\text { As(III) }\end{array}$ & $\begin{array}{c}\text { 6-8.5 for } \mathrm{As}(\mathrm{V}) \\
7.5-9.5 \text { for } \\
\mathrm{As}(\mathrm{III})\end{array}$ & Cheap & $\begin{array}{l}\text { Long contact time; } \\
\text { low As(III) removal }\end{array}$ & (31) \\
\hline $\begin{array}{l}\text { Kaolinite clay } \\
\text { minerals }\end{array}$ & $\begin{array}{l}1: 40 \text { rock:water } \\
\text { ratio }\end{array}$ & & $\begin{array}{c}50 \% \text { for } \\
\text { As(III), 90- } \\
100 \% \text { for } \\
\mathrm{As}(\mathrm{V})\end{array}$ & $16 \mathrm{~h}$ & $\begin{array}{c}\text { Both } \\
\text { As }(\mathrm{V}) \text { and } \\
\text { As(III) }\end{array}$ & $\begin{array}{c}-8.5 \text { for } \mathrm{As}(\mathrm{V}) \\
7.5-9.5 \text { for } \\
\mathrm{As}(\mathrm{III})\end{array}$ & Cheap & $\begin{array}{l}\text { Long contact time; } \\
\text { low As(III) removal }\end{array}$ & (31) \\
\hline $\begin{array}{l}\text { Soyatal } \\
\text { formation }\end{array}$ & $\begin{array}{c}1: 2,1: 10, \text { or } \\
1: 20 \text { solid: } \\
\text { water weight } \\
\text { ratio }\end{array}$ & $\begin{array}{l}\text { About half of } \\
\text { samples } \\
\text { have } \\
\sim 500 \mu \mathrm{g} / \mathrm{L}\end{array}$ & $\begin{array}{c}94 \% \text { for } \\
\text { crushed rock }\end{array}$ & $\begin{array}{l}24 \mathrm{~h} \\
\text { frequent } \\
\text { shaking }\end{array}$ & $\begin{array}{l}\mathrm{As}(\mathrm{V}) \\
\text { predomin } \\
\text { antly }\end{array}$ & $\begin{array}{c}\mathrm{pH} \text { average of } \\
7.1\end{array}$ & $\begin{array}{l}\text { Cheap, simple, } \\
\text { abundant; high } \\
\text { arsenic removal } \\
\text { efficiency }\end{array}$ & Long contact time & $(26)$ \\
\hline $\begin{array}{l}\text { Manganese } \\
\text { greensand }\end{array}$ & $\begin{array}{c}.005 \mathrm{~m}^{3} \\
\text { greensand + } \\
10 \mathrm{~g} \mathrm{KMnO}_{4} \text { in } \\
972 \mathrm{ml}\end{array}$ & $100 \mu \mathrm{g} / \mathrm{L}$ & $81 \%$ & $\begin{array}{c}\text { Filtration rate } \\
\text { of } 1.5 \\
\mathrm{~L} / \mathrm{min} / \mathrm{m}^{2}\end{array}$ & $\begin{array}{l}\text { As }(\text { III) and } \\
\text { oxidizing } \\
\text { agent }\end{array}$ & $\begin{array}{c}\text { Around } \\
\text { neutral pH; } \mathrm{pH} \\
\text { not adjusted } \\
\text { or tested }\end{array}$ & & Expensive & $(7)$ \\
\hline Goethite & $1 \mathrm{~g} / \mathrm{L}$ & $10 \mu \mathrm{g} / \mathrm{L}$ & $\begin{array}{l}\text { Near- } \\
\text { complete } \\
\text { removal at } \\
3<\mathrm{pH}<6\end{array}$ & $\begin{array}{c}1 \mathrm{~h} \\
\text { contact time }\end{array}$ & $\mathrm{As}(\mathrm{V})$ & $\begin{array}{c}\mathrm{pH} \mathrm{3-9,} \mathrm{but} \\
\text { high residual } \\
\text { turbidity at } \mathrm{pH} \\
>5\end{array}$ & $\begin{array}{l}\text { Can remove both } \\
\text { cations and anions }\end{array}$ & $\begin{array}{l}\text { Best at } \mathrm{pH} \text { range } \\
3-5 ; \text { high turbidity } \\
\text { outside that range }\end{array}$ & $(27)$ \\
\hline Hydrotalcite & $1 \mathrm{~g} / \mathrm{L}$ & $20 \mu \mathrm{g} / \mathrm{L}$ & Well over $90 \%$ & $10-15 \mathrm{~h}$ & $\mathrm{As}(\mathrm{V})$ & Test & & High ionic strength & (29) \\
\hline
\end{tabular}


Table 3. Summary of Technologies Reviewed

\begin{tabular}{|c|c|c|c|c|c|c|c|c|c|}
\hline Sorbent & $\begin{array}{c}\text { Amount of } \\
\text { Sorbant Used }\end{array}$ & $\begin{array}{c}\text { Range of } \\
\text { Arsenic } \\
\text { Tested }\end{array}$ & Efficiency & $\begin{array}{l}\text { Reaction } \\
\text { Time }\end{array}$ & $\begin{array}{c}\text { Arsenic } \\
\text { Species } \\
\text { Tested }\end{array}$ & $\mathrm{pH}$ & Advantage & Disadvantage & $\begin{array}{l}\text { Work } \\
\text { Cited }\end{array}$ \\
\hline & & & & & & $\begin{array}{c}\text { conducted at } \\
\text { natural } \mathrm{pH}\end{array}$ & & $\begin{array}{l}\text { needed for best } \\
\text { removal; } \\
\text { complicated } \\
\text { procedure } \\
\end{array}$ & \\
\hline $\begin{array}{l}\text { Mesoporous } \\
\text { anion trap } \\
\text { (Cu-EDA-Si) }\end{array}$ & $10 \mathrm{~g} / \mathrm{L}$ & $\begin{array}{c}1.0 \mathrm{mg} / \mathrm{L} \\
\text { and higher }\end{array}$ & $98.5 \%$ & $\begin{array}{c}\text { Shaken } \\
\text { overnight for } \\
12 \mathrm{~h}\end{array}$ & $\mathrm{As}(\mathrm{V})$ & $\begin{array}{l}\text { Solutions } \\
\text { tested } \\
\text { generally had } \\
\text { pH } 5 \text { and } 6\end{array}$ & $\begin{array}{l}\text { Not affected by } \\
\text { anion competition } \\
\text { for adsorbent site; } \\
\text { high arsenic } \\
\text { removal }\end{array}$ & $\begin{array}{l}\text { High-tech } \\
\text { operation }\end{array}$ & $(30)$ \\
\hline $\begin{array}{l}\text { Gravel bed } \\
\text { containing iron- } \\
\text { coated sand }\end{array}$ & $\begin{array}{c}80 \mathrm{~mL} \text { of } 2 \mathrm{M} \\
\mathrm{FeNO}_{3} \text { per } 200 \\
\mathrm{~cm}^{2} \text { sand }\end{array}$ & $300 \mu \mathrm{g} / \mathrm{L}$ & $\begin{array}{l}200-225 \text { bed } \\
\text { volumes }\end{array}$ & $\begin{array}{l}\text { Several } \\
\text { minutes }\end{array}$ & Both & & $\begin{array}{l}\text { Can remove both } \\
\mathrm{As}(\mathrm{III}) \text { and } \mathrm{As}(\mathrm{V}) \\
\text { indiscriminately. } \\
(4,35) \text {; sand can } \\
\text { be regenerated }\end{array}$ & $\begin{array}{l}\text { Toxic waste } \\
\text { sludge; } \\
\text { complicated } \\
\text { process to make } \\
\text { sand }\end{array}$ & (23) \\
\hline $\begin{array}{c}\text { Gravel bed } \\
\text { containing iron } \\
\text { sludge }\end{array}$ & & $300 \mu \mathrm{g} / \mathrm{L}$ & $50 \%$ & & Both & & $\begin{array}{l}\text { Low removal } \\
\text { efficiency }\end{array}$ & $\begin{array}{l}\text { Does not adhere } \\
\text { well to gravels; } \\
\text { sensitive to flow } \\
\text { rate }\end{array}$ & (23) \\
\hline $\begin{array}{c}\text { Clinoptilolite- } \\
\text { bearing zeolites, } \\
\text { ZH }\end{array}$ & & $\begin{array}{c}100 \mathrm{ml} \text { of } \\
\text { untreated } \\
\text { water }\end{array}$ & Efficient & $\begin{array}{l}\text { At least } 4 \\
\text { days }\end{array}$ & Both & & $\begin{array}{l}\text { Cheap, can be } \\
\text { found everywhere }\end{array}$ & $\begin{array}{l}\text { Very long contact } \\
\text { time; water needs } \\
\text { to be further } \\
\text { filtered after } \\
\text { treatment }\end{array}$ & (11) \\
\hline Calcium oxide & $\begin{array}{c}0.1 \% \\
\text { lime/water ratio } \\
\text { by weight }\end{array}$ & & $99.9 \%$ & $16 \mathrm{~h}$ & & & $\begin{array}{l}\text { High arsenic } \\
\text { removal }\end{array}$ & $>10 \mathrm{~h}$ contact time & $(32)$ \\
\hline Wood charcoal & $600-757$ & & $97-99 \%$ & $\begin{array}{c}12-45 \\
\mathrm{~mL} / \mathrm{min}\end{array}$ & & & $\begin{array}{l}\text { High removal } \\
\text { shown, but not all } \\
\text { studies suggested } \\
\text { so }\end{array}$ & Complicated & (32) \\
\hline Laterite & $5 g$ & & $50-90 \%$ & $10 \mathrm{~min}$ & Both & & Brief contact time & $\begin{array}{l}\text { Low removal } \\
\text { efficiency }\end{array}$ & (22) \\
\hline
\end{tabular}




\section{CHEMISTRY AND MECHANISMS OF SOME MAJOR SORBENTS}

The following is a description of the reactions responsible for arsenic sequestration by the various technologies described in Section 5. Unbalanced reactions are written to highlight important species.

Ferric salts: $\mathrm{As}(\mathrm{III})$ and $\mathrm{Fe}^{2+}$ are oxidized to $\mathrm{As}(\mathrm{V})$ and $\mathrm{Fe}^{3+}$ respectively. Ferric chloride reacts with water and form $\mathrm{Fe}(\mathrm{OH})_{3}$, which strongly adsorbs $\mathrm{As}(\mathrm{V})$ (4).

$$
\begin{array}{ll}
\mathrm{Fe}^{2+}(\mathrm{II})+\mathrm{NaClO} \rightarrow \mathrm{Fe}^{3+} & \text { Oxidation } \\
\mathrm{As}(\mathrm{III})+\mathrm{NaClO} \rightarrow \mathrm{As}(\mathrm{V}) & \text { Oxidation } \\
\mathrm{FeCl}{ }_{3}+\mathrm{H}_{2} \mathrm{O} \rightarrow \mathrm{Fe}(\mathrm{OH})_{3} & \text { Iron precipitation } \\
\mathrm{Fe}(\mathrm{OH})_{3}(\mathrm{~s})+\mathrm{H}_{3} \mathrm{AsO}_{4} \rightarrow \mathrm{FeAsO}_{4} \cdot 2 \mathrm{H}_{2} \mathrm{O}+\mathrm{H}_{2} \mathrm{O} & \text { Iron complex }
\end{array}
$$

Aluminum co-precipitation: Alum dissociates in water and forms aluminum hydroxide, which co-precipitates with arsenic (4).

$$
\begin{array}{ll}
\mathrm{Al}_{2}\left(\mathrm{SO}_{4}\right)_{3} \bullet 18 \mathrm{H}_{2} \mathrm{O} \rightarrow 2 \mathrm{Al}^{3+} & \text { Alum dissolution } \\
2 \mathrm{Al}^{3+}+6 \mathrm{H}_{2} \mathrm{O} \rightarrow 2 \mathrm{Al}\left(\mathrm{OH}_{3}\right)_{3}+6 \mathrm{H}^{+} & \text {Aluminum precipitation } \\
\mathrm{H}_{2} \mathrm{AsO}_{4}{ }^{-}+\mathrm{Al}(\mathrm{OH})_{3} \rightarrow \mathrm{Al}-\mathrm{As} \text { complex } & \text { Co-precipitation }
\end{array}
$$

Iron filings: Under aerobic conditions $\mathrm{Fe}^{\mathrm{o}}$ is oxidized to $\mathrm{Fe}^{2+}$, resulting in depletion of $\mathrm{O}_{2}$ in water, and anoxic conditions eventually develop. Further reductions can produce a stable FeAsS precipitate. Therefore, the presence of sulfate is important for removing arsenic. An iron oxide layer could also form on the surface of $\mathrm{Fe}^{\mathrm{o}}$ due to corrosion, and this layer was likely the predominant adsorption site for both As species (15).

$$
14 \mathrm{Fe}^{2+}+\mathrm{SO}_{4}{ }^{2-}+\mathrm{AsO}_{3}{ }^{3-}+14 \mathrm{H}^{+} \rightarrow \mathrm{FeAsS}+13 \mathrm{Fe}^{3+}+7 \mathrm{H}_{2} \mathrm{O} \quad \text { Co-precipitation }
$$

Lanthanum hydroxide (LH): Two proposed mechanisms for arsenic removal by lanthanum hydroxides are adsorption by exchange of $\mathrm{OH}^{-}$group with As ions in the neutral to basic $\mathrm{pH}$ range when $\mathrm{La}$ does not dissolve $\left[\mathrm{La}(\mathrm{OH})_{3}\right]$, and precipitation of insoluble lanthanum arsenate, $\mathrm{LaAsO}_{4}$, in the acid $\mathrm{pH}$ range when $\mathrm{La}$ is dissolved $\left(\mathrm{La}^{3+}\right)$ (17); for example:

$$
\begin{array}{ll}
\mathrm{La}(\mathrm{OH})_{3}+\mathrm{H}_{2} \mathrm{AsO}_{4}{ }^{-} \rightarrow \mathrm{La}\left(\mathrm{H}_{2} \mathrm{AsO}_{4}\right)_{3}+3 \mathrm{OH}^{-} & \text {Adsorption reaction } \\
\mathrm{La}^{3+}+\mathrm{H}_{2} \mathrm{AsO}_{4}{ }^{-} \rightarrow \mathrm{LaAsO}_{4}+2 \mathrm{H}^{+} & \text {Precipitation reaction }
\end{array}
$$

Adsorption of $\mathrm{HasO}_{4}{ }^{2-}$ can also occur in the alkaline range.

Strong base anion-exchanger: A strong base anion-exchanger can remove only the pentavalent form of arsenic, $\operatorname{As}(\mathrm{V})(4,33)$.

$$
\begin{aligned}
& \mathrm{R}-\mathrm{Cl}+\mathrm{H}_{2} \mathrm{AsO}_{4}{ }^{-} \rightarrow \mathrm{R}_{-} \mathrm{H}_{2} \mathrm{AsO}_{4}+\mathrm{Cl}^{-} \\
& 2 \mathrm{R}-\mathrm{Cl}+\mathrm{HAsO}_{4}{ }^{2-} \rightarrow \mathrm{R}_{2}-\mathrm{HAsO}_{4}+2 \mathrm{Cl}^{-}
\end{aligned}
$$


where R stands for organic ligand of the anion exchange resin.

Birnessite: $\mathrm{MnO}_{2}$ oxidizes $\mathrm{As}(\mathrm{III})$ and some $\mathrm{As}(\mathrm{V})$ gets adsorbed to the hydroxyl group on $\mathrm{MnO}_{2}$ surface (18).

$$
\begin{array}{ll}
\mathrm{MnO}_{2}+\mathrm{H}_{3} \mathrm{AsO}_{3}+2 \mathrm{H}^{+} \rightarrow \mathrm{Mn}^{2+}+\mathrm{H}_{3} \mathrm{AsO}_{4} & \text { Oxidation of As(III) } \\
2 \mathrm{Mn}--\mathrm{OH}+\mathrm{H}_{3} \mathrm{AsO}_{4} \rightarrow(\mathrm{MnO})_{2} \mathrm{AsOOH}+2 \mathrm{H}_{2} \mathrm{O} & \text { Adsorption of As(V) }
\end{array}
$$

Mesoporous anion traps: $\mathrm{Cu}-\mathrm{EDA}-\mathrm{Si}$ (30). Initially, $\mathrm{Cu}(\mathrm{II})$ is bonded to ethylenediamine ligands to form octahedral complexes on the surface of the mesoporous silica. This gives rise to a shape with a positive charge that can match the geometry of tetrahedral arsenic anions. The binding begins with electrosteric coordination, followed by displacement of one ligand and direct binding with the $\mathrm{Cu}(\mathrm{II})$ center.

Hydrotalcite materials (29): Hydrotalcite-like compounds have the general formula $\left[\mathrm{M}_{1-\mathrm{x}}{ }^{2+} \mathrm{M}_{\mathrm{x}}^{3+}(\mathrm{OH})_{2}\right]\left(\mathrm{A}^{\mathrm{n}-}\right)_{\mathrm{x} / \mathrm{n}} \bullet \mathrm{yH}_{2} \mathrm{O} . \quad \mathrm{M}^{2+}$ and $\mathrm{M}^{3+}$ are divalent and trivalent metal ions, respectively, $\mathrm{A}^{\mathrm{n}-}$ is a $\mathrm{n}$-valent exchangeable anion and $\mathrm{x}$ can have values between 0.2 and 0.33 . Unlike anion-exchanger resins, which induce an ion exchange reaction with a hydrated anion, hydrotalcite compounds induce reactions with bare, nonhydrated anions.

Goethite (18): Goethite is an $\tilde{\alpha}$-iron(III) hydroxy-oxide mineral $[\mathrm{FeO}(\mathrm{OH})]$. Arsenic is removed through surface complexation with goethite.

Soyatal Formation (26): A possible mechanism for arsenic removal by Soyatal Formation rocks is adsorption of arsenic to clay minerals in the calcareous shale. 


\section{TECHNOLOGY EVALUATION}

Developing countries like Vietnam and Bangladesh cannot afford expensive and/or largescale treatments. Low-cost, effective technologies that are readily available at the household or community level are needed to solve the present crisis. Large-scale treatments are not appropriate because many people in third-world countries obtain water from wells rather than from large municipal water plants. Appropriate in-home technologies to be implemented in third-world countries should meet certain criteria to be effective. The treatment must be applicable over a wide range of arsenic concentrations and easy to use without running water or electricity, and the materials for the treatment must be cheap, readily available, and/or reusable to reduce costs. Finally, such technology should not introduce any harmful chemicals into drinking water (15).

Quite often it is a very complex task to select a method because of the many difficulties that arise when a particular technology is applied in the field. These difficulties include a wide range of arsenic concentrations, effects of other elements and their variable concentrations in water, the need to adjust $\mathrm{pH}$ for optimal removal, optimized dose, proper operation and maintenance, and safe disposal of arsenic waste (35). Another major issue concerning a technology is that it should not pose risk of bacteriological contamination and should be broadly acceptable to users. Field studies in Bangladesh showed that the main reasons for rejection of some technologies are the amount of operational effort, the level of maintenance, the amount of time until clean water is available, and the volume of water that the technologies can provide on a daily basis (36).

Our review of arsenic removal technologies indicates that iron filings, ferric salts, granular ferric hydroxide, alumina manganese oxide, lanthanum hydroxide, Aqua-bind ${ }^{\mathrm{m}}$, and Kimberlite tailings are potentially low-cost sorbents that can remove arsenic after simple mixing in a relatively short time. The most well known treatment makes use of a ferric salt (such as ferric chloride and ferric sulfate). Ferric salts are cheap and very effective at removing arsenic. Ion exchange resins can remove $\mathrm{As}(\mathrm{V})$ very well, but competing anions such as nitrate and sulfate strongly reduce arsenic removal potential. Therefore, this sorbent is not practical to use in groundwaters where anions such as nitrate and sulfate are present in high concentrations. The next-most-effective very common arsenic technology consists of a fixed column of sorbents that can remove arsenic simply by passing groundwater through the column. The most well known fixed-bed columns make use of activated alumina and iron-coated sands. These fixed bed columns often do not work well with groundwater having high concentrations of iron because iron precipitates in the presence of air, which could clog and foul the column.

Many synthetic sorbents have also recently been developed that have many advantages over other sorbents. These synthetic sorbents are highly selective and effective and do not often pose much waste disposal concern since they are usually non-hazardous. Aqua-bind ${ }^{\mathrm{TM}}$ is perhaps the most effective synthetic sorbent available for removing arsenic, but it must be massproduced to realize low cost. Aqua-bind can be used as a fixed-bed column that can be attached directly to wells. 
Naturally occurring solids also remove arsenic well, but the removal rate is often very slow. The advantages of using naturally occurring solids over other sorbents are that they are cheap and often can be obtained free of charge. One difficulty that has surfaced from using these natural solids is that the treated water often harbors bacteria.

Another highly innovative treatment makes use of biological oxidation. Certain bacteria are cultured to oxidize iron and manganese, which are often present in high concentrations in groundwater. Arsenic was removed through adsorption to the iron and manganese solids. One advantage of this technology is that all three contaminants, Fe, Mn, and As, are removed simultaneously. 


\section{FUTURE OPPORTUNITY: REMOVAL OF ARSENIC USING MAGNETIC PARTICLES}

This report serves as a basis for comparing existing candidate technologies with magnetic particle technology. Most of the technologies discussed have slow reaction rates and are not very simple to use. The quest for a simple, low-cost, effective technology that can remove arsenic in a short time is still ongoing.

Magnetic particle technology may provide a viable, low-cost option. This procedure would consist of adding functionalized magnetic particles directly to a drinking water storage vessel or small pitcher. After stirring the contents with a spoon for a short period, the magnetic particles would be removed with a simple bar magnet. A plastic sheath around the magnet can be removed to free the bar magnet for additional use. The particles may be regenerated similarly to the technologies described above, depending on the functional material sorbed to the surface of the magnetic particles.

The advantage of magnetic particle technology stems from high surface areas and simplified water clarification. Magnetic particles for arsenic removal would have to be composed of magnetic material (magnetite) of very small size $(<10 \mu \mathrm{m})$. To take advantage of the properties of iron, manganese, and alumina, they may be co-precipitated with the magnetite to increase its versatility in treating arsenic under various $\mathrm{pH}$. The reaction rates may be greater because the reactions occur at the high specific surface areas. Fouling would be avoided since these particles are not kept in a static column but are removed after each cleaning and can be dried and stored. The cost of this technology has not been evaluated but the magnetite or coprecipitated magnetite is expected to be more expensive than naturally occurring material like Kimberlite tailings.

More thorough evaluation is needed to determine the efficacy of magnetic particles in removing arsenic. 


\section{REFERENCES}

1. Smedley P.L., Nicolli H.B., Macdonald D.M.J., Barros A.J., Tullio J.O. (2002) Hydrogeochemistry of arsenic and other inorganic constituents in groundwaters from La Pampa, Argentina. Applied Geochemistry. 17, 259-284.

2. Khan A.H., Rasul S.B., Munir A., Habibuddowla M., Alauddin M., Newaz S.S. and Hussan A. (2000) Appraisal of a simple arsenic removal method for groundwater of Bangladesh. J. Environ. Sci. Health. 35 (7), 1021-1041.

3. Amjad S., N. Chandra, C.D. Anuradha and Seishiro Hirano. (2002) Speciation of arsenic in tube-well water samples collected from West Bengal, India, by high-performance liquid chromatography-inductively coupled plasma mass spectrometry. Applied organometallic chemistry. Applied organometallic Chemistry. 16, 202-209.

4. Ahmed F.M. 2001. "An overview of arsenic removal technologies in Bangladesh and India.” In: M. Feroze Ahmed. et al. 2001 (Eds). Technologies for Arsenic Removal from Drinking Water. A compilation of papers presented at the International Workshop on Technologies for Arsenic Removal from Drinking Water. Bangladesh University of Engineering and Technology, Dhaka, Bangladesh and the United Nations University, Tokyo. May 2001.

5. Ravenscroft P., McArthur J.M. and Hoque B.A. (2001) Geochemical and Palaeohydrological Controls on Pollution of Groundwater by Arsenic. In: Arsenic Exposure and Health Effects IV. W.R. Chappell, C.O. Abernathy \&R. Calderon (Eds), Elsevier Science Ltd. Oxford.

6. Kinniburgh D.G., Smedley P.L., Trafford J.M., Milne C.J.., Hug S.M.I., Ahmed K.M., Burden S., 2001. The National Hydrochemical Survey. In: Kinniburgh D.G. and Smedley P.L. (Eds.), Arsenic Contamination of Groundwater in Bangladesh. Volume 2: Final Report. British Geological Survey Report, WC/00/19. British Geological Survey, UK (Chapter 6), pp. 77-103.

7. Viraraghavan T., Subramanian K.S. and Aruldoss J.A. (1999) Arsenic in drinking waterProblems and solutions. Water Science Technology. 40 (2), 69-76.

8. Johnston R. and Heijnen H. 2001. "Safe Water Technology for Arsenic Removal." In: M. Feroze Ahmed. et al. 2001 (Eds). Technologies for Arsenic Removal from Drinking Water. A compilation of papers presented at the International Workshop on Technologies for Arsenic Removal from Drinking Water. Bangladesh University of Engineering and Technology, Dhaka, Bangladesh and the United Nations University, Tokyo. May 2001.

9. Smedley P.L. and Kinniburg D.G. (2002) A review of the source, behavior and distribution of arsenic in natural waters. Applied Geochemistry. 17, 517-568. 
10. Jain C.K. and Ali I. (2000) Arsenic: occurrence, toxicity and speciation techniques. Water Research. 34(17), 4304-4312.

11. Elizalde-Gonzalez M.P., Mattusch J., Wennrich R., Morgenstern P. (2001) Sorption on natural solids for arsenic removal. Chemical Engineering Journal. 81, 187-195.

12. Berg M., Tran C.H., Nguyen C.T., Pham V.H., Schertenleib R. and Giger W. (2001) Arsenic Contamination of Groundwater and Drinking Water in Vietnam: A Human Health Threat. Environmental Science and Technology. 35(13), 2621-2626.

13. Wolfgang D., Reiner S. and Martin J. (1995) Oxidation of arsenate (III) with manganese oxides in water treatment. Water Research. 29 (1), 297-305.

14. Jalil M.A. and Ahmed F. 2001. "Development of an activated alumina based household arsenic removal unit." In: M. Feroze Ahmed. et al. 2001 (Eds). Technologies for Arsenic Removal from Drinking Water. A compilation of papers presented at the International Workshop on Technologies for Arsenic Removal from Drinking Water. Bangladesh University of Engineering and Technology, Dhaka, Bangladesh and the United Nations University, Tokyo. May 2001.

15. Ramaswami A., Tawachsupa S. and Isleyen M. (2001) Batch-mixed iron treatment of high arsenic waters. Water Research. 35(18) 4474-4479.

16. Su C. and Puls W.R. (2001) Arsenate and Arsenite Removal by Zerovalent Iron: Kinetics, Redox Transformation, and Implications for in situ groundwater remediation. Environ. Sci. Technol. 35, 1487-1492

17. Tokunaga S., Wasay S.A., and Park S.W, (1997) Removal of arsenic (V) ion from aqueous solutions by Lanthanum compounds. Water Science Technology. 35 (7), 71-78.

18. Manning A.B., Fendorf E.S., Bostick B. and Suarez L.D. (2002) "Arsenic (III) Oxidation and Arsenic (V) Adsorption Reactions on Synthetic Birnessite." Environmental Science and Technology. 36(5), 976-981.

19. Senapati K. and Alam I. 2001. "Apyron Arsenic Treatment Unit-Reliable Technology for Arsenic Safe Water." In: M. Feroze Ahmed. et al. 2001 (Eds). Technologies for Arsenic Removal from Drinking Water. A compilation of papers presented at the International Workshop on Technologies for Arsenic Removal from Drinking Water. Bangladesh University of Engineering and Technology, Dhaka, Bangladesh and the United Nations University, Tokyo. May 2001. 
20. Pal B.N. 2001. "Granular Ferric Hydroxide for Elimination of Arsenic from Drinking Water." In: M. Feroze Ahmed. et al. 2001 (Eds). Technologies for Arsenic Removal from Drinking Water. A compilation of papers presented at the International Workshop on Technologies for Arsenic Removal from Drinking Water. Bangladesh University of Engineering and Technology, Dhaka, Bangladesh and the United Nations University, Tokyo. May 2001.

21. Kepner, B., Spotts, J., Mintz, E., Cortopassi, E., Abrahams, P., Gray, C., and Matur, S. (1998) Removal of arsenic from drinking water with enhanced hybrid aluminas and composite metal oxide particles. Presentation at the Feb. 1998 International Conference on Arsenic Pollution of Groundwater: Causes, Effects, Remedies, Dhaka Community Hospital, Dhaka, Bangladesh.

22. Sharmin, N. 2001. "Arsenic Removal Processes on Trial in Bangladesh." In: M. Feroze Ahmed. et al. 2001 (Eds). Technologies for Arsenic Removal from Drinking Water. A compilation of papers presented at the International Workshop on Technologies for Arsenic Removal from Drinking Water. Bangladesh University of Engineering and Technology, Dhaka, Bangladesh and the United Nations University, Tokyo. May 2001.

23. Ali A.M., Badruzzaman A.B.M., Jalil M.A., Hossain D.M., Hussainuzzaman M.M., Badruzzaman M., Mohammad O.I., Akter N. 2001. "Development of Low-cost Technologies for Removal of Arsenic from Groundwater." In: M. Feroze Ahmed. et al. 2001 (Eds). Technologies for Arsenic Removal from Drinking Water. A compilation of papers presented at the International Workshop on Technologies for Arsenic Removal from Drinking Water. Bangladesh University of Engineering and Technology, Dhaka, Bangladesh and the United Nations University, Tokyo. May 2001.

24. Dikshit A.K., Pallamreddy K., Praveen Reddy L.V. and Saha J.C. (2000) Arsenic in groundwater and its sorption by Kimberlite tailings. J. Environ. Sci. Health. 35 (1), 65-85.

25. Katsoyiannis I., Zouboulis A., Althoff $\mathrm{H}$ and Bartel H. (2002) As(III) removal from groundwaters using fixed-bed upflow bioreactors. Chemosphere. 47 325-332.

26. Ongley K.L., Armienta A.M., Heggeman K., Lathorop A.S., Mango H., Miller W. and Pickelner S. (2001) Arsenic removal from contaminated water by the Soyatal Formation, Zimapan Mining District, Mexico-a potential low-cost low-tech remediation system. Geochemistry: Exploration, Environment, Analysis. 2, 0-9.

27. Matis K.A., Zouboulis A.I., Zamboulis D. and Valtadorou A.V. (1999) Sorption of As(V) by goethite particles and study of their flocculation. Water, Air, and Soil Pollution. 111, 297-316.

28. Bajpai, S. and Chaudhuri, M. (1999) "Removal of arsenic from ground water by manganese dioxide--coated sand." Journal of Environmental engineering. 126(12), 782783. 
29. Lazaridis N.K., Hourzemanoglou A. and Matis K.A. (2002) Flotation of metal-loaded clay anion exchangers Part II: the case of arsenates. Chemosphere. 47, 319-324.

30. Fryxell G.E., Liu J., Hauser T.A., Nie Z., Ferris K. F., Mattigod S., Gong M., and Hallen R. T., (1999). Design and Synthesis of Selective Mesoporous Anion Traps. Chem. Mater. 11, 2148-2154.

31. Manning B. A., and Goldberg S., (1997) "Adsorption and Stability of Arsenic (III) at the Clay Mineral—Water Interface,” Environ. Sci. Technol. 31(7) 2005-2011.

32. Hussain M.D., Haque M.A., Islam M.M. and Hossen M.A. 2001. "Approaches for Removal of Arsenic from Tubewell Water for Drinking Purpose. " In: M. Feroze Ahmed. et al. 2001 (Eds). Technologies for Arsenic Removal from Drinking Water. A compilation of papers presented at the International Workshop on Technologies for Arsenic Removal from Drinking Water. Bangladesh University of Engineering and Technology, Dhaka, Bangladesh and the United Nations University, Tokyo. May 2001.

33. Korngold E., Belayev N. and Aronov L. (2001) Removal of arsenic from drinking water by anion exchangers. Desalination. 141, 81-84.

34. Das D., Chatterjee A., Samanta G., Chowdhury T.R., Mandal B.K., Dhar R., Chanda R.C., Lodh D., Chowdhury P.P., Basu G.K., Biswas K.B., Chowdhury U.K., Rahman M.M>, Paul K. and Chakraborti D. 2001. "A Simple Household Device to Remove Arsenic from Groundwater and Two Years Performance Report of Arsenic Removal Plant for Treating Groundwater with Community Participation" In: M. Feroze Ahmed. et al. 2001 (Eds). Technologies for Arsenic Removal from Drinking Water. A compilation of papers presented at the International Workshop on Technologies for Arsenic Removal from Drinking Water. Bangladesh University of Engineering and Technology, Dhaka, Bangladesh and the United Nations University, Tokyo. May 2001.

35. Dikshit K., Saha C. J. and Bandyopadhyay M. 2001. "Comparative Studies for Selection of Technologies for Arsenic Removal from Drinking Water.” In: M. Feroze Ahmed. et al. 2001 (Eds). Technologies for Arsenic Removal from Drinking Water. A compilation of papers presented at the International Workshop on Technologies for Arsenic Removal from Drinking Water. Bangladesh University of Engineering and Technology, Dhaka, Bangladesh and the United Nations University, Tokyo. May 2001.

36. Sutherland D., Kabir O.M. and Chowdhury A.N. 2001. "Rapid Assessment of Technologies for Arsenic Removal at the Household Level. Proceedings" In: M. Feroze Ahmed. et al. 2001 (Eds). Technologies for Arsenic Removal from Drinking Water. A compilation of papers presented at the International Workshop on Technologies for Arsenic Removal from Drinking Water. Bangladesh University of Engineering and Technology, Dhaka, Bangladesh and the United Nations University, Tokyo. May 2001. 
Distribution for ANL/CMT-03/02

Internal (Printed Copies):

L. Nuñez

G. F. Vandegrift

M. D. Kaminski (5)

S. K. Zussman

Internal (Electronic Copies):

M. R. Hale, TIS

D. Lewis

External (Electronic Copies):

M. A. Buckley, Library-E

E. Sackett, Library-W

Chemical Technology Division Review Committee Members:

H. U. Anderson, University of Missouri-Rolla, Rolla, MO

R. A. Greenkorn, Purdue University, West Lafayette, IN

C. L. Hussey, University of Mississippi, University, MS

M. V. Koch, University of Washington, Seattle, WA

V. P. Roan, Jr., University of Florida, Gainesville, FL

J. R. Selman, Illinois Institute of Technology, Chicago, IL

J. S. Tulenko, University of Florida, Gainesville, FL 